\title{
Italian Vascular Flora: New Findings, Updates and Exploration of Floristic Similarities between Regions
}

\author{
Adriano Stinca $1, *(0)$, Carmelo Maria Musarella ${ }^{2, *(\mathbb{D})}$, Leonardo Rosati ${ }^{3, *} \mathbb{0}$, Valentina Lucia Astrid Laface ${ }^{2}$, \\ Wolfgang Licht ${ }^{4}$, Emanuele Fanfarillo ${ }^{5}$, , Robert Philipp Wagensommer ${ }^{6}$, Gabriele Galasso ${ }^{7}$,

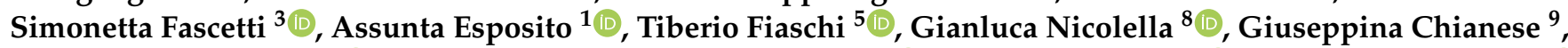

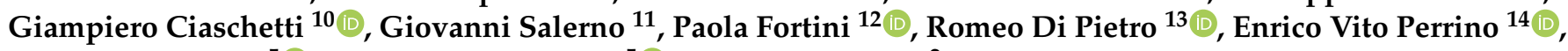 \\ Claudia Angiolini ${ }^{5}$, Leopoldo De Simone ${ }^{5}$ and Giacomo $\mathrm{Mei}^{2}$
}

check for updates

Citation: Stinca, A.; Musarella, C.M.; Rosati, L.; Laface, V.L.A.; Licht, W.; Fanfarillo, E.; Wagensommer, R.P.; Galasso, G.; Fascetti, S.; Esposito, A.; et al. Italian Vascular Flora: New Findings, Updates and Exploration of Floristic Similarities between Regions. Diversity 2021, 13, 600. https:// doi.org/10.3390/d13110600

Academic Editor: Michael Wink

Received: 30 September 2021

Accepted: 17 November 2021

Published: 21 November 2021

Publisher's Note: MDPI stays neutral with regard to jurisdictional claims in published maps and institutional affiliations.

Copyright: (c) 2021 by the authors. Licensee MDPI, Basel, Switzerland. This article is an open access article distributed under the terms and conditions of the Creative Commons Attribution (CC BY) license (https:/ / creativecommons.org/licenses/by/ $4.0 /)$.
1 Department of Environmental, Biological and Pharmaceutical Sciences and Technologies, University of Campania Luigi Vanvitelli, 81100 Caserta, Italy; assunta.esposito@unicampania.it

2 Department of Agraria, Mediterranea University of Reggio Calabria, 89122 Reggio Calabria, Italy; vla.laface@unirc.it (V.L.A.L.); giacomo.mei@unirc.it (G.M.)

3 School of Agricultural, Forestry, Food and Environmental Sciences, University of Basilicata, 85100 Potenza, Italy; simonetta.fascetti@unibas.it

4 Institute of Organismic and Molecular Evolution, Johannes Gutenberg-University Mainz, 55122 Mainz, Germany; wlicht@outlook.de

5 Department of Life Sciences, University of Siena, 53100 Siena, Italy; emanuele.fanfarillo@unisi.it (E.F.); tiberio.fiaschi@gmail.com (T.F.); claudia.angiolini@unisi.it (C.A.); leopoldo.desimone@unisi.it (L.D.S.)

6 Department of Biology, University of Bari “Aldo Moro", 70125 Bari, Italy; robert.wagensommer@uniba.it

7 Section of Botany, Natural History Museum of Milano, 20121 Milano, Italy; gabriele.galasso@comune.milano.it

8 Independent Researcher, Via di Valle Melaina 61, 00139 Roma, Italy; loka75@libero.it

9 Museum Center "Museums of Agricultural Sciences", University of Naples Federico II, 80055 Portici, Italy; giuseppina.chianese@unina.it

10 Maiella National Park, 67039 Sulmona, Italy; giampiero.ciaschetti@parcomajella.it

11 Department of Sciences, "Roma Tre" University, 00146 Rome, Italy; giovanni.salerno@uniroma3.it

12 Department of Bioscience and Territory, University of Molise, 86090 Pesche, Italy; fortini@unimol.it

13 Department of Planning, Design and Architecture Technology, Sapienza University of Roma, 00196 Roma, Italy; romeo.dipietro@uniroma1.it

14 CIHEAM, Mediterranean Agronomic Institute of Bari, 70010 Valenzano, Italy; enricoperrino@yahoo.it

* Correspondence: adriano.stinca@unicampania.it (A.S.); carmelo.musarella@unirc.it (C.M.M.); leonardo.rosati@unibas.it (L.R.)

Abstract: The tradition of floristic studies in Italy has made it possible to obtain a good knowledge of plant diversity both on a national and regional scale. However, the lack of knowledge for some areas, advances in plant systematics and human activities related to globalization, highlight the need for further studies aimed at improving floristic knowledge. In this paper, based on fieldwork and herbaria and literature surveys, we update the knowledge on the Italian vascular flora and analyze the floristic similarities between the administrative regions. Four taxa, all exotic, were recorded for the first time in Italy and Europe. In detail, Elaeodendron croceum, Kalanchoë blossfeldiana, and Sedum spathulifolium var. spathulifolium were found as casual aliens, while Oxalis brasiliensis was reported as historical record based on some herbarium specimens. Furthermore, Kalanchoë laxiflora was confirmed as a casual alien species for Italy and Europe. Status changes for some taxa were proposed at both national and regional levels, as well as many taxa were reported as new or confirmed at the regional level. Currently the Italian vascular flora comprises 9150 taxa of which 7547 are native (of which 1598 are Italian endemics) and 1603 are exotic at the national level. The multivariate analysis of updated floristic data on a regional scale showed a clear distribution along the latitudinal gradient, in accordance with the natural geographical location of the regions in Italy. This pattern of plants distribution was not affected by the introduction of alien species. Despite some taxonomic and methodological issues which are still open, the data obtained confirm the important role of floristic investigations in the field and in herbaria, as well as the collaborative approach among botanists, in order to improve the knowledge of the Italian and European vascular flora. 
Keywords: Apennine peninsula; biological recording; exotic species; floristic inventories; floristic studies; herbaria; herborization; invasive plants; Italy; native species; new floristic records; plant diversity; regional flora

\section{Introduction}

Italy boasts a long tradition of floristic studies both nationally and locally. In the 15th and 16th centuries, many botanists (e.g., Benedetto Rinio, Luca Ghini and Ulisse Aldrovandi) mostly investigated the present-day area of northern Italy, while in the post-Linnaean period and until the early 1900s it was above all southern Italy and the islands that aroused the interest of researchers (e.g., Michele Tenore, Giovanni Gussone and Giuseppe Giacinto Moris) [1] Starting from the second post-war period, floristic research was extended to most of Italy, making it possible to acquire good knowledge of plant biodiversity, also thanks to the activism of a large group of botanists belonging to the working group for Floristics, Systematics and Evolution of the Italian Botanical Society. Over time, field surveys, together with systematic studies performed in herbaria, have enabled the publication of national floras [1-7], some prior to the political unification of Italy [8-10]. However, in recent decades, Italy has witnessed considerable advances also in plant systematics. This has led to the description of many new taxa [11-14], the revision of some critical groups [15-18], and other taxonomic [19-23] and biogeographic insights [24-27]. Furthermore, a new flora of Italy was recently proposed for the identification of taxa [28-31], and many nomenclatural changes were put forward, often based on molecular studies carried out by other authors and poorly supported by clear morphological evidence (for example within Fabaceae, Melilotus Mill. was related with other genera of the tribe Trifolieae, first to Medicago L. and then to Trigonella L. [32]), which can cause confusion among scholars.

Thanks to the collaboration of many researchers, the Italian checklists of native and exotic flora was recently published [33,34], facilitating the work of botanists and providing a standardized nomenclature of vascular plants reported for Italy. Both floristic inventories report for Italy's 20 regions the distribution of species, subspecies and some hybrids (only for alien taxa) on the basis of knowledge updated to 2018. The above data have been subsequently updated by several researchers [35-45]. A first summary of these updates is given by Bartolucci et al. [46] who report 7528 native and 1564 exotic taxa as certainly occurring in Italy. However, despite the importance for scientific and conservation purposes [47], floristic knowledge of Italy's flora is far from exhaustive: in addition to the incomplete knowledge of some groups (e.g., Anthyllis vulneraria aggr., Centaurea deusta aggr., Micromeria graeca aggr. and Ziziphora granatensis aggr. [48]), for large swathes of the country the data are still scant or outdated [49]. Urban development is known to bring about the local extinction of species [50,51] and promote the invasion and dispersal of alien plant species [52,53]. As these processes are exacerbated by global climate change, updating past floristic inventories is a critical scientific endeavor to monitor, predict, and manage current and future impacts of climate change itself [54]. Therefore, it is important that frequent assessment of national and regional floras is undertaken not only to monitor the established populations (indigenous and naturalized), but also to update the distribution data to enable the early warning of declines in indigenous or endemic species, and to document the introduction of invasive plants [41]. Indeed, updating knowledge on vascular plant distribution represents a very important research topic in the Mediterranean area which is recognized as a global biodiversity hotspot [55].

The overall objective of this study is to improve the knowledge of Italian vascular flora. Specific goals of this research are: (a) to report new taxa for Italy; (b) to update the distribution of already known taxa and their status of presence at the national and regional level; (c) to make a synthesis on the current floristic knowledge in Italy; (d) to analyze the floristic similarities between the 20 Italian administrative regions, assuming a great differences between the native flora of the regions along the North-South geographic 
gradient and an increase in similarities between regions due to the introduction of nonnative species.

\section{Materials and Methods}

\subsection{Study Area}

Italy is situated in South Europe on the central-northern shores of the Mediterranean basin (between $12^{\circ} 11^{\prime} 10^{\prime \prime} \mathrm{E}$ to $12^{\circ} 36^{\prime} 21^{\prime \prime} \mathrm{E}$, and $47^{\circ} 05^{\prime} 31^{\prime \prime} \mathrm{N}$ to $35^{\circ} 29^{\prime} 35^{\prime \prime} \mathrm{N}$ ) (Figure $1 \mathrm{~A}$ ). It is divided into 20 administrative regions and covers a total area of $302,068.3 \mathrm{~km}^{2}$ (Figure $1 \mathrm{~B}$ ). From a geographical point of view, within its territory three macro-areas can be distinguished: continental Italy (i.e., northern areas between the border with France, Switzerland, Austria and Slovenia and the southern border of Emilia-Romagna), peninsular Italy (i.e., between the regional border indicated above and the South of the Italian Peninsula as far as Puglia and Calabria), and insular Italy (i.e., Sicilia and Sardegna which are the two largest islands in the Mediterranean Sea) (Figure 1B).
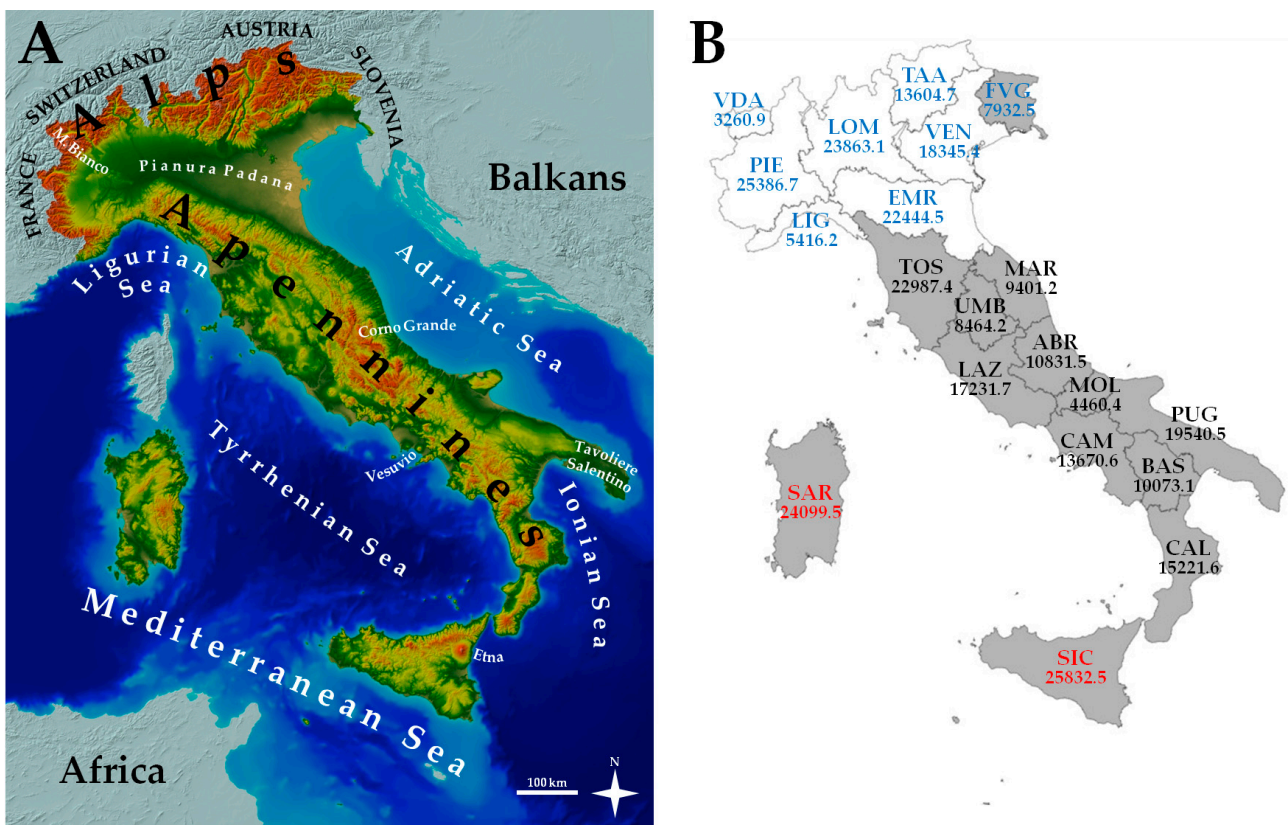

Figure 1. (A) Location and geographical features of Italy (from Tarquini et al. [56], modified). (B) Division into administrative regions of the Italian territory (VDA: Valle d'Aosta; PIE: Piemonte; LOM: Lombardia; TAA: Trentino-Alto Adige; VEN: Veneto; FVG: Friuli-Venezia Giulia; LIG: Liguria; EMR: Emilia-Romagna; TOS: Toscana; UMB: Umbria; MAR: Marche; LAZ: Lazio; ABR: Abruzzo; MOL: Molise; CAM: Campania; BAS: Basilicata; PUG: Puglia; CAL: Calabria; SIC: Sicilia; and SAR: Sardegna) with the indication of continental (regions in blue), peninsular (regions in black), and insular Italy (regions in red). The number under the abbreviated name of each region indicates its area in $\mathrm{km}^{2}$. Regions for which we provide new floristic data on the basis of our study are highlighted in gray.

As is well known, Italy has an extraordinary physiographic, geological, pedological and land use variability. It is characterized by the presence of two large mountain ranges, namely the Alps and the Apennines (Figure 1A). The Alps, which represent the largest mountain range in Europe, cross most of continental Italy from the East to the West and include the highest peaks of the continent such as Monte Bianco (4810 $\mathrm{m}$ a.s.1.), while the Apennines extend for about $1200 \mathrm{~km}$ in the Italian Peninsula and have the highest elevation on Corno Grande (2912 m a.s.l.). Additionally, the active volcanic districts such as Etna in Sicilia (3350 $\mathrm{m}$ a.s.1.) and Vesuvio in Campania (1281 $\mathrm{m}$ a.s.1.) are noteworthy. The lowlands represent almost a quarter of the national territory and are almost entirely cultivated (e.g., Pianura Padana and Tavoliere Salentino). Overall, the coastline is about $7900 \mathrm{~km}$ in length. The largest urban areas are located around the main cities, namely Roma, Milano and Napoli. With about 59 million inhabitants [57], Italy is the third most populous member 
state of the European Union, after Germany and France. According to the Bioclimatic map of Europe [58], Italy has two main temperate bioclimates (continental, oceanic) and one Mediterranean (pluvioseasonal oceanic).

\subsection{Data Sources}

The floristic data are based on field investigations carried out from 2011 to 2021, herbaria surveys and bibliographic analysis. The collected or examined plant material is preserved in public herbaria registered (APP, BI, CAT, FI, HFLA, HLUC, IS, MJG-Herb. Garganicum, MS, MSNM, PI, PORUN-Herb. Stinca, REGGIO, RO-HL, SIENA) and not (Herb. Magellense of the Maiella National Park) in the Index Herbariorum [59], or private herbaria (Herb. G. Mei, Herb. R.P. Wagensommer). In the floristic list, taxa are arranged in alphabetical order. Nomenclature, taxa delimitation, and notes on the regional distribution follow the checklists of Italian vascular flora $[33,34]$ and their updates [60-73] also available on the information system "FlorItaly-Portal to the Flora of Italy" (http:/ / dryades.units.it/floritaly/index.php, accessed on 8 November 2021 [74]).

The collected or observed specimens were identified according to Flora Europaea [75-79], Flora d'Italia [28-31], Flora of North America [80], Flora of China [81], Flora do Brasil [82], and some monographic works cited in the species' notes in the floristic list. In these same notes the literature used for nomenclature and identification of taxa which are new for Italy are reported.

For each taxon the following information are provided:

- Accepted name;

- Plant family;

- Life form according to the categories of Flora d'Italia [28-31] and verified by on-field observations;

- Current chorology for indigenous plants or native range for exotic ones according to POWO [83];

- Period of introduction in Italy (i.e., archaeophyte or neophyte) for exotic plants;

- Data report in the study area;

- Only for exotic taxa, the current invasiveness status for each region, assessed by population monitoring over time according to the terminology of Pyšek et al. [84];

- Additional notes, including possible negative impacts of exotic taxa on habitats of interest to the European Community (Habitat Directive 92/43/EEC, https:/ / eur-lex.europa.eu/legal-content/EN/TXT/?uri=celex\%3A31992L0043, accessed on 10 November 2021).

Finally, sites of finds (i.e., exsiccata and observata) with details on the location (toponyms in Italian), growth environment(s), altitude, date, geo-coordinates $\mathrm{E}$ and $\mathrm{N}$ (datum WGS84, UTM); collector(s) (i.e., legit), author(s) of the identification (i.e., determinavit) are shown in Table S1.

Our new floristic data as well as those recently published in the series "Notulae to the Italian native vascular flora" [60-66] and "Notulae to the Italian alien vascular flora" [67-73], and related in the Supplementary Materials, were used to update the previous data of taxa in Italy and in each administrative region [33,34].

\subsection{Data Analysis}

A multivariate analysis using XLSTAT software [85] was applied to test the degree of floristic similarity between regions. Data matrices, of taxa currently present in Italian regions (i.e., binary data: presence/absence), used for the analysis were: (i) only native taxa; (ii) only exotic taxa; (iii) total taxa. Taxa reported by mistake and as doubts, data deficient, extinct and were no longer recorded after 1950 were not considered for the analysis. The matrices were then processed by agglomerative hierarchical clustering (AHC, using Ward's method) and by principal component analysis (PCA, with the application of the Euclidean biplot) to the graphical exploration of the distances among Italian regions.

The floristic comparison between the regions was also carried out using the following indices:

- $\mathrm{R} t n=$ the richness of total native taxa (including cryptogenics) (n.); 
- $\mathrm{R} t a=$ the richness of total alien taxa (including casual, naturalized, invasive and not assessed) (n.);

- $\quad \mathrm{FP}=$ the degree of floristic pollution (i.e., total alien taxa/total flora $\times 100)(\%)$;

- $\operatorname{Ren}=$ the richness of exclusive native taxa (i.e., regional endemics + taxa with wider distribution but reported in only one Italian region) (n.; \%);

- $\quad$ Rea $=$ the richness of exclusive alien taxa (n.; \%);

- $\quad \operatorname{Ree}=$ the richness of exclusive endemics (i.e., regional endemics) (n.; \%);

- $\mathrm{D} t n=$ the density of total native taxa (i.e., number of total native taxa/area) $\left(\operatorname{taxa} / \mathrm{km}^{2}\right)$;

- $\mathrm{D} t a=$ the density of total alien taxa (i.e., number of total native taxa/area) (taxa $\left./ \mathrm{km}^{2}\right)$;

- $\mathrm{DN} n=$ the normalized density of total native taxa (i.e., natural logarithm of the number of total native taxa/natural logarithm of area) $\left(\mathrm{taxa} / \mathrm{km}^{2}\right)$;

- $\mathrm{DN} t a=$ the normalized density of total alien taxa (i.e., natural logarithm of the number of total native taxa/natural logarithm of area) $\left(\mathrm{taxa} / \mathrm{km}^{2}\right)$.

In addition, to better quantify the role of each regional flora on the national flora we propose a new index called the regional floristic index (RFI). RFI is the result of the ratio between the number of taxa occurring in the region and the average number of taxa present in all regions. It can be greater or less than 1 if the number of taxa occurring in the region is greater or less than the average number of taxa present in all regions, respectively. We calculated the value of this index considering only native taxa (RFIn), only alien taxa (RFI $a$ ) and the total taxa (RFIt) present in each Italian region.

\section{Results}

Below we report the list of the floristic notes that contribute to update the data on the Italian flora. Details on the floristic data collected (i.e., exsiccata and observata, n. 400) are reported in Table S1. A summary of our results is shown in Table 1.

Table 1. New floristic records for the Italian regions according to our field, herbarium and literature researches (CAL: Calabria; UMB: Umbria; TOS: Toscana; MAR: Marche; CAM: Campania; PUG: Puglia; LAZ: Lazio; BAS: Basilicata; SAR: Sardegna; ABR: Abruzzo; MOL: Molise; FVG: Friuli-Venezia Giulia; VEN: Veneto; and SIC: Sicilia).

\begin{tabular}{|c|c|c|c|c|c|c|}
\hline $\begin{array}{l}\text { Italian } \\
\text { Regions }\end{array}$ & $\begin{array}{c}\text { First } \\
\text { Records } \\
\text { (n.) }\end{array}$ & $\begin{array}{c}\text { Confirmations } \\
\text { (n.) }\end{array}$ & $\begin{array}{l}\text { Exclusions } \\
\text { (n.) }\end{array}$ & $\begin{array}{c}\text { Changes } \\
\text { of Status } \\
\text { (n.) }\end{array}$ & $\begin{array}{c}\text { First } \\
\text { Geolocalized } \\
\text { Reports } \\
\text { (n) }\end{array}$ & $\begin{array}{c}\text { Total } \\
(\text { n.) }\end{array}$ \\
\hline CAL & 5 & 1 & 1 & 37 & & 44 \\
\hline UMB & 10 & 1 & & 3 & & 14 \\
\hline TOS & 4 & & & 8 & & 12 \\
\hline MAR & 10 & & & 1 & & 11 \\
\hline CAM & 9 & 1 & & 1 & 1 & 12 \\
\hline PUG & 4 & 2 & & 2 & 2 & 10 \\
\hline LAZ & 3 & & & 7 & & 10 \\
\hline BAS & 4 & 1 & & 2 & & 7 \\
\hline SAR & 4 & & & 1 & & 5 \\
\hline ABR & 3 & 1 & & & & 4 \\
\hline MOL & 1 & & & & 1 & 2 \\
\hline FVG & 1 & & & & & 1 \\
\hline VEN & 1 & & & & & 1 \\
\hline SIC & & 1 & & & & 1 \\
\hline Total (n.) & 59 & 8 & 1 & 62 & 4 & 134 \\
\hline
\end{tabular}

\subsection{Floristic List}

Acanthus mollis L. subsp. mollis

Acanthaceae-Hemicryptophyta scaposa-Mediterranean area (?)

Change of status for Campania: from cryptogenic to invasive alien 
Notes-A very popular geophyte as an ornamental plant and in architecture since the Graeco-Roman era [30]: for this reason, its native range is difficult to define today. In Italy Acanthus mollis subsp. mollis is considered as a native plant only in some southern Italian regions and Sicilia, while in Campania it is classified as a cryptogenic species [33]. In this region, it is widespread in anthropogenic environments and disturbed forests [86-89] (see also our findings in Table S1), where it reproduces through abundant seed production. Its invasiveness is evident in the urban and peri-urban holm oak woods that can be attributed to the habitat 9340 (Quercus ilex and Quercus rotundifolia forests). In these plant communities A. mollis subsp. mollis competes with many native species such as Asplenium onopteris L., Brachypodium sylvaticum (Huds.) P.Beauv. subsp. sylvaticum, Cyclamen hederifolium Aiton subsp. hederifolium, Drymochloa drymeja (Mert. \& W.D.J.Koch) Holub subsp. exaltata (C.Presl) Foggi \& Signorini, Limodorum abortivum (L.) Sw., Rubia peregrina L., as well as with seedlings of Fraxinus ornus L. subsp. ornus and Quercus ilex L. subsp. ilex. Therefore, we propose this species as an invasive alien in Campania, in agreement with the other central-northern Italian regions and Sardegna.

\section{Actinidia deliciosa (A.Chev.) C.F.Liang \& A.R.Ferguson}

Actinidiaceae-Phanerophyta lianosa-China-Neophyte

First record for Campania (casual alien)

Notes-This species, native to China and often cultivated for fruits in Italy [29], was reported as casual in Piemonte, Lombardia, Trentino-Alto Adige, Veneto, Liguria, Emilia Romagna, Toscana and Lazio $[34,69,71,73]$. Therefore, our recent findings in Castellammare di Stabia (Napoli) (Figure 2A) are the first in Campania and concern a few plants spread by seed.

\section{Amaryllis belladonna L.}

Amaryllidaceae-Geophyta bulbosa-South Africa-Neophyte

Change of status for Calabria: from casual alien to naturalized alien

Notes-Amaryllis belladonna is a geophyte native to South Africa, often cultivated as an ornamental plant in Italy [28]. It is reported as a naturalized alien for Liguria, Campania and Sicilia, while it is considered a casual alien in Lombardia, Puglia and Calabria [34,69]. However, in the latter region it frequently grows on slopes where there are oak woods with Quercus pubescens Willd. subsp. pubescens, generally in the vicinity of villages and it blooms every year from its bulbs which remain in situ (i.e., Calanna, Reggio Calabria, and Santo Stefano in Aspromonte). Hence, the species can be considered naturalized for Calabria.

\section{Andrachne telephioides L.}

Phyllanthaceae-Chamaephyta suffrutescentia-Mediterranean-South-East Asia

New distribution data for Italian rare species in Lazio (native)

New distribution data for Italian rare species in Campania (native)

Notes-Andrachne telephioides is a chamaephyte which has its current center of distribution from the Mediterranean to South-East Asia. In peninsular Italy it was reported as a native plant in many regions including Lazio and Campania, while it is considered a casual alien in Veneto and cryptogenic in Toscana [33,62,64]. According to the literature, this species was indicated in Lazio by Anzalone et al. [90] for the dry uncultivated and railway embankments of Roma, Bagni di Tivoli and Minturno. In Campania it was reported only in the South of the region for the train station of Sicignano degli Alburni by Salerno [91], and by De Natale [92] for the natural environments of Capo Palinuro in Centola municipality. Our discoveries of the species in and near the railway embankments of Roma (here also occurs in the parking area of the Engineering Department of the "Roma Tre" University), Bagni di Tivoli (i.e., two of the three localities reported by Anzalone et al. [90] and Caserta fuel doubts about its native status in these regions. 


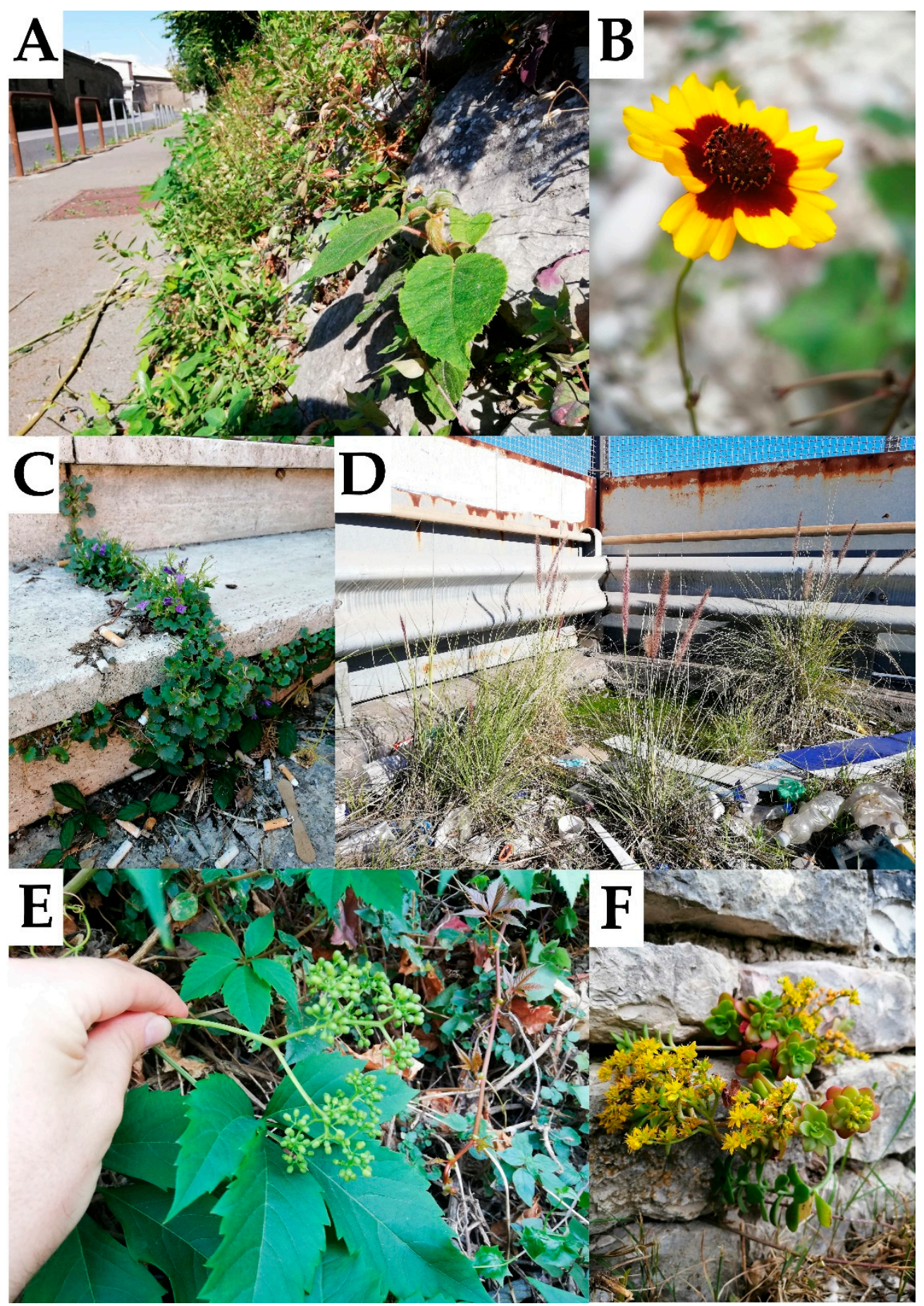

Figure 2. Some taxa reported as new for Italy and its regions. (A) Actinidia deliciosa (Campania, Castellammare di Stabia, 4 August 2019, photo: A. Stinca). (B) Bidens tinctoria (Marche, Cagli, 4 August 2021, photo: G. Mei). (C) Campanula portenschlagiana (Marche, Cagli, 30 August 2021, photo: G. Mei). (D) Cenchrus setaceus (Campania, Castellammare di Stabia, 1 January 2020, photo: A. Stinca). (E) Parthenocissus inserta (Campania, Castellammare di Stabia, 21 August 2021, photo: A. Stinca). (F) Sedum spathulifolium var. spathulifolium (Marche, Cagli, 4 May 2021, photo: G. Mei).

Antirrhinum majus L. subsp. majus

Plantaginaceae-Chamaephyta fruticosa-South-West Europe (?)—Archaeophyte Change of status for Calabria: from casual alien to naturalized alien 
Notes-This taxon was reported as naturalized for all Italian regions, except Valle $\mathrm{d}^{\prime}$ Aosta and Calabria where it is considered as a casual alien [34]. However, we report here new records from four out five provinces of Calabria (i.e., Calanna, Decollatura, Oriolo, Motta San Giovanni, Reggio Calabria, and Vallelonga) where the species shows long established populations with several mature individuals that produce seeds. Hence, the species may be considered naturalized for Calabria.

\section{Araujia sericifera Brot.}

Apocynaceae-Phanerophyta lianosa-South America-Neophyte

Change of status for Lazio: from casual alien to naturalized alien

Notes-Araujia sericifera is a liana native to central-eastern South America. According to the literature data $[34,71,73]$, in Italy it was often reported as a casual or naturalized alien for many regions, except for Campania where it was indicated as invasive [93]. This neophyte was recorded for several localities in Lazio [94-96] and indicated as a casual alien by Galasso et al. [34]. However, based on the stabilized populations reproducing by seed and recently monitored in the municipality of Roma, we propose the status of naturalized in Lazio for this species. The naturalization of this species is worrying because it is generally a secondary host for viruses harmful to crops [97].

\section{Arctotheca calendula (L.) Levyns}

Asteraceae-Therophyta scaposa-South Africa-Neophyte

Change of status for Calabria: from naturalized alien to invasive alien

Notes-Arctotheca calendula is a therophyte native to South Africa, sometimes cultivated as an ornamental plant in Italy (A. Stinca, pers. comm.). It is reported as a casual alien for Trentino-Alto Adige and Sicilia, while it is considered a naturalized alien in Calabria and Sardegna [34]. Compared to the first report for the Italian Peninsula by Crisafulli et al. [98] from Calabria, in which only two reports were made for the same locality, the species has now expanded its range, having recently been found at new sites along the coast of Reggio Calabria province (i.e., Reggio Calabria, San Ferdinando, and Villa San Giovanni) where it was not present before. Here, it tends to invade the coastal dunes with habitats 2110 (embryonic shifting dunes) and 2120 (shifting dunes along the shoreline with Ammophila arenaria (white dunes)). In these plant communities A. calendula competes with many native species such as Cakile maritima Scop. subsp. maritima, Calamagrostis arenaria (L.) Roth subsp. arundinacea (Husn.) Banfi, Galasso \& Bartolucci, Convolvulus soldanella L., Euphorbia peplis L., Medicago marina L., Pancratium maritimum L. and Polygonum maritimum L. Therefore, we propose the status of invasive in Calabria for this neophyte.

Artemisia campestris L. subsp. campestris

Asteraceae-Chamaephyta suffrutescentia-Subcosmopolitan

Confirmation for Abruzzo (native)

Notes-The Italian distribution range of this taxon, includes all northern regions, Basilicata and Sicilia, while it is reported as doubtful for Abruzzo [33]. However, a review of the specimen conserved in the Herb. Magellense of the Maiella National Park using Tison and De Foucault [99] and Pignatti et al. [30] led to a correction of the previous attribution of the specimen to Artemisia campestris L. subsp. glutinosa (J.Gay ex Besser) Batt. The same correction has to be made in the phytosociological relevè of the Loto cretici-Sixalicetum grandiflorae Pirone, Ciaschetti, Di Martino, Frattaroli, Cianfaglione \& Giallonardo published in Pirone et al. [100], while the records of A. campestris subsp. glutinosa in the Echinophoro spinosae-Ammophiletum arundinaceae (Br.-Bl. 1933) Géhu, Rivas-Martínez, Tüxen 1972 and Junco maritimi-Spartinetum junceae Biondi 1992 associations that can be found in the same paper require further investigations.

Asparagus setaceus (Kunth) Jessop

Asparagaceae-Phanerophyta lianosa-East and South Africa-Neophyte

Change of status for Calabria: from casual alien to naturalized alien 
Notes-Asparagus setaceus is an African liana, sometimes cultivated as an ornamental plant in Italy [28]. It is reported as a naturalized alien for Campania and Sicilia, while it is considered as casual alien in Trentino-Alto Adige, Toscana, Lazio, Puglia, Calabria and Sardegna $[34,69,72]$. In Calabria, it was recently reported as casual for some localities in Reggio Calabria province [101]. Due to the new sites discovered for this same territory (i.e., Reggio Calabria and Villa San Giovanni) where adult mature individuals are forming stabilized populations, the species should be considered naturalized for the region.

\section{Astragalus penduliflorus Lam.}

Fabaceae-Hemicryptophyta scaposa-European Orophyte

New distribution data for Italian rare species in Lazio (native)

Notes-Astragalus penduliflorus is a bushy perennial herb that occurs in grasslands of the montane and subalpine belt of some European mountains such as the Alps. Consequently, in Italy it occurs in the northern regions [33] and can be considered a rare species. An isolated population (a relict) was also discovered in the central Apennines by Lattanzi et al. [102]. These authors found only a few individuals near Colle del Vento (1500 m a.s.l.) on the Lazio side (Tyrrhenian side) of the Monti della Laga. However, in the following years the species was no longer found, so much so as to suggest that it was locally extinct (R. Di Pietro, pers. comm.). Fortunately, about thirty tufts were recently observed at Stazzo della Pacina in the municipality of Amatrice, once again on the Tyrrhenian side of the Monti della Laga. This important find confirms the presence of $A$. penduliflorus in the peninsular Italy.

\section{Bidens formosa (Bonato) Sch.Bip.}

Asteraceae-Therophyta scaposa-North America-Neophyte

First record for Lazio (casual alien)

Notes-The North American Bidens formosa is a cultivated ornamental plant in Italy, where it also occurs as a casual alien in several regions [34,72]. In Lazio, in an anthropogenic site within Alatri municipality, we discovered a small population composed by few individuals spread by the seed of plants cultivated nearby. After the first find in October 2019, it was observed in the same site in autumn 2020.

\section{Bidens frondosa $\mathrm{L}$.}

Asteraceae-Therophyta scaposa-North America-Neophyte Change of status for Toscana: from naturalized alien to invasive alien

Notes-This American herb is considered invasive in most of Italian regions [34]. In Toscana, where it was considered naturalized [34], we recorded it as abundant in riparian environments along the Fiume Arbia, where it often outcompetes the native Bidens tripartita L. We thus propose to change its status from naturalized to invasive in Toscana.

\section{Bidens subalternans DC.}

Asteraceae-Therophyta scaposa-South America-Neophyte

Change of status for Puglia: from naturalized alien to invasive alien

Notes-Bidens subalternans is a South American therophyte introduced in Italy, but here often confused with similar species, such as Bidens bipinnata L. (A. Stinca, pers. comm.). This neophyte was recorded as a naturalized or invasive alien from many Italian regions except for Valle d'Aosta, Piemonte, Veneto, Calabria and Sardegna [34,69,72,73]. In Puglia, it is considered as a naturalized alien by Galasso et al. [34]. However, as observed in the Capurso, Carovigno, San Giovanni Rotondo, Manfredonia and Vico del Gargano municipalities in the same region, this species is rapidly colonizing many anthropogenic environments, such as roadsides and cultivated land. Therefore, we propose the status of invasive in Puglia for this neophyte.

Bidens tinctoria (Nutt.) Baill. ex Daydon

Asteraceae-Therophyta scaposa-North and Central America-Neophyte First record for Marche (casual alien) 
Notes-This American species in Italy was reported as a casual escapee from cultivation in Lombardia and Veneto [34]. Recently, we discovered a new population on the banks of the Fiume Bosso in Cagli (Marche) (Figure 2B). Therefore, the new find extends its range to the South and is the first report for peninsular Italy.

Boerhavia coccinea Mill.

Nyctaginaceae-Chamaephyta fruticosa-North, Central and South America—Neophyte First record for Campania (naturalized alien)

Notes-Species native to the Neotropics, Boerhavia coccinea in Italy occurs as a naturalized alien in Calabria and Sicilia [34]. A large population was also discovered in southern Campania (Sapri), where it shows a noticeable propagation by seed in anthropogenic environments and appears stabilized. Therefore, the new discovery extends its Italian range to the North.

Broussonetia papyrifera (L.) Vent.

Moraceae-Phanerophyta caespitosa—South and South-East Asia-Neophyte

Change of status for Calabria: from casual alien to naturalized alien

Notes-In Calabria, this species was first reported by Pignatti [1], then confirmed as casual for the region by [71]. In the different populations reported herein (i.e., Cirò Marina, Fiumara, Melito di Porto Salvo, Montebello Jonico, and Motta San Giovanni), individuals were born in the vicinity of adult trees and created small populations with numerous plants, some of which are reproductive. Hence, the species can be considered naturalized for Calabria.

Campanula portenschlagiana Schult.

Campanulaceae-Hemicryptophyta scaposa-Balkans-Neophyte

First record for Marche (casual alien)

Change of status for Toscana: from casual alien to naturalized alien

Notes-Campanula portenschlagiana is a hemycryptophyte native to the Balkan area. The species is sometimes cultivated as an ornamental plant in Italy. It was reported as a casual alien for Lombardia, Trentino-Alto Adige, Friuli-Venezia Giulia, Veneto, Liguria, Emilia-Romagna, Toscana, Umbria and Abruzzo [34,72,73,103]. In Cagli (Marche; Figure 2C), a small population was discovered consisting of a few individuals, probably spread by the seeds of nearby cultivated plants, which grow in the fractures of the floor and an external staircase of a disused building on the outskirts of the town. Instead, the population discovered in the urban center of Asciano in Toscana appears clearly stabilized, a region for which the status of naturalized is proposed for this neophyte.

Canna indica L.

Cannaceae-Geophyta rhizomatosa-North, Central and South America—Neophyte First record for Umbria (casual alien)

Notes-Canna indica is an American perennial often cultivated as an ornamental plant in Italy [28]. To date it occurs as a casual and naturalized alien in several Italian regions [34,71]. The individuals found in Umbria (Tuoro sul Trasimeno and Perugia) probably derive from vegetative parts present in the soil brought back.

\section{Cenchrus setaceus (Forssk.) Morrone}

Poaceae — Hemicryptophyta caespitosa — North and East Africa and the Arabian Peninsula—Neophyte First record for Campania (naturalized alien)

Notes-The hemycryptophyte Cenchrus setaceus was recorded in Italy as casual in Toscana and Lazio, naturalized in Puglia and invasive in Calabria, Sicilia and Sardegna [34,71,72]. Two populations were also discovered in Campania (Castellammare di Stabia and Nocera Inferiore; Figure 2D) in anthropogenic environments. In particular, in Castellammare di Stabia, it has shown a considerable propagation by seed and appears stabilized. 
Centaurium erythraea Rafn subsp. rhodense (Boiss. \& Reut.) Melderis

Gentianaceae-Hemicryptophyta biennia-Steno-Mediterranean

Confirmation for Basilicata (native)

Notes-Centaurium erythraea subsp. rhodense was indicated in Liguria, Lazio, Puglia, Calabria, Sicilia and Sardegna, while it is reported as doubtful for Basilicata [33]. A specimen traced in HLUC collected at Lido di Metaponto (Bernalda) on May 1991, confirms the presence of this taxon in Basilicata, in geographical continuity with neighboring regions.

\section{Ceratochloa cathartica (Vahl) Herter}

Poaceae-Hemicryptophyta caespitosa-South America-Neophyte First record for Basilicata (casual alien)

Notes-Ceratochloa cathartica, a hemycryptophyte often cultivated in the lawns of Italian urban areas (A. Stinca, pers. comm.), was recorded as a casual or naturalized alien species for almost all Italian regions except for Molise and Basilicata [34]. In Basilicata, it was probably overlooked in the past; however, at present it must be considered as a casual species, based on a small population recently discovered in Potenza.

Cerinthe retorta $\mathrm{Sm}$.

Boraginaceae-Therophyta scaposa-East Steno-Mediterranean

New distribution data for Italian rare species in Puglia (native)

Notes-Cerinthe retorta is a therophyte having its current center of distribution in the southern Balkans and Turkey [104]. Wagensommer et al. [105] recorded it in the Gargano promontory (Valle dell'Inferno, in the municipality of San Giovanni Rotondo) in the Puglia region as a new taxon for Italy, based on a specimen collected in April 2013. Therefore, our discovery in the Gravina di Laterza (Laterza municipality), within the Regional Park of Terra delle Gravine, in May 2005 can be considered the first in Italy (but was misidentified until today) and represents the new southernmost limit of its Italian distribution. This species is very interesting from a phytogeographical point of view because it is a plant with eastern distribution that exhibits a disjunct Italian distribution, more or less restricted to Puglia, like other species such as Bromus parvispiculatus H.Scholz [106], Carex phyllostachys C.A.Mey. [107,108] and Scrophularia lucida L. [109].

Chamaecyparis lawsoniana (A.Murray) Parl.

Cupressaceae-Phanerophyta scaposa-North America-Neophyte

First record for Marche (casual alien)

First record for Umbria (casual alien)

Notes-Chamaecyparis lawsoniana, native to North America, is sometimes cultivated for ornamental and reforestation purpose in Italy [28]. Here, it is recorded as casual in Lombardia, Trentino-Alto Adige, Veneto, Friuli-Venezia Giulia, Emilia-Romagna, Toscana, Abruzzo and Sardegna [34,70,73]. In Marche and Umbria, we discovered two small populations composed by young individuals spread by the seeds of this neophyte in reforestation areas of Cagli and Gualdo Tadino, respectively.

Chasmanthe floribunda (Salisb.) N.E.Br.

Iridaceae-Geophyta bulbosa-South Africa-Neophyte

Change of status for Calabria: from casual alien to naturalized alien

Notes-Reported as casual for Calabria by Galasso et al. [34], this species forms very numerous plant groups. The populations presented here (i.e., Palizzi and Reggio Calabria) were found in the indicated stations for several years and bloom every year. Therefore, the species can be considered naturalized for the region.

Chimonanthus praecox (L.) Link

Calycanthaceae-Phanerophyta caespitosa-China-Neophyte

First record for Marche (casual alien)

Notes-Chimonanthus praecox, a popular ornamental tree in Italy (A. Stinca, pers. comm.), was previously recorded as casual only for Trentino-Alto Adige [34]. The discovery 
of two small populations of this species in the Marche region (Cagli) is thus the second report for Italy and the first relating to peninsular Italy.

\section{Chlorophytum comosum (Thunb.) Jacques}

Asparagaceae-Hemicryptophyta scaposa-Africa-Neophyte

First record for Umbria (casual alien)

First record for Lazio (casual alien)

Notes-Chlorophytum comosum is an evergreen perennial plant native to tropical and southern Africa. In Italy the species is present as an accidental escapee in Lombardia, Abruzzo, Calabria and Sardegna [34,72], while it is naturalized in Campania [89]. In Umbria (Terni) and Lazio (Orte) we discovered two small populations probably derived from vegetable waste from plants cultivated in nearby areas.

Coleus scutellarioides (L.) Benth.

Lamiaceae-Hemicryptophyta scaposa-South-East Asia and Australia-Neophyte First record for Calabria (casual alien)

Notes-Hemicryptophyte native to South-East Asia, Coleus scutellarioides in Italy is sometimes cultivated as an ornamental plant (A. Stinca, pers. comm.). It was indicated as casual only in Lombardia [34]. Recently, a small population of this neophyte, probably spread by seeds from plants nearby cultivated, were observed in anthropogenic environments in Verbicaro in Calabria. Therefore, the new discovery is the first for the Italian Peninsula.

Cortaderia selloana (Schult. \& Schult.f.) Asch. \& Graebn.

Poaceae-Hemicryptophyta caespitosa-South America-Neophyte

Change of status for Lazio: from casual alien to naturalized alien

Notes-Cortaderia selloana was recorded for several localities in Lazio [96] and indicated as a casual alien by Galasso et al. [34]. However, based on the stabilized populations reproducing vegetatively and by seeds reported in the literature [96] or recently monitored (Ferentino), we propose the status of naturalized in Lazio for this species.

Crassula muscosa L.

Crassulaceae-Chamaephyta suffrutescentia-South Africa-Neophyte Change of status for Calabria: from naturalized alien to invasive alien

Notes-A chamaephyte native to South Africa, in Italy it is reported as a casual escapee in Toscana, Marche, Campania and Sicilia, while it is naturalized in Liguria, Calabria and Sardegna [34,70]. However, in several localities in the province of Reggio Calabria (i.e., Campo Calabro, Reggio Calabria, and San Lorenzo), the species grows abundantly on the roofs of old abandoned houses and in dry stone walls, while some individuals are found in drainage ditches. We thus propose to change its status in Calabria from naturalized to invasive alien.

\section{Crepis sancta (L.) Bornm. subsp. nemausensis (P.Fourn.) Babc.}

Asteraceae-Therophyta scaposa-East Mediterranean-Neophyte

Change of status for Toscana: from naturalized alien to invasive alien

Notes-This East Mediterranean taxon quickly spread across Italy during the last 150 years [30]. Nowadays, it is considered as naturalized in all the Italian regions but Sicilia (where its occurrence is doubtful), and it is invasive in Lombardia, Veneto, Marche and Campania [34]. In Toscana, this species is considered as naturalized, though it is widespread all over the region [110]. Based on this evidence and on abundant populations observed in Asciano (Siena), we propose to change its status in Toscana from naturalized to invasive alien. Moreover, in the aforementioned locality as well as in the olive groves (where it competes with Aphanes australis Rydb., Medicago arabica (L.) Huds., Trifolium nigrescens Viv. subsp. nigrescens, Veronica arvensis L., etc.), Crepis sancta subsp. nemausensis grows on the travertine walls with xerothermophile pioneer communities which can be attributed to the habitat $6110^{*}$ (rupicolous calcareous or basophilic grasslands of the Alysso-Sedion albi). In these plant communities $C$. sancta subsp. nemausensis competes with some native species 
such as Arenaria leptoclados (Rchb.) Guss. subsp. leptoclados, Campanula erinus L., Petrosedum rupestre (L.) P.V.Heath, Poa bulbosa L. subsp. bulbosa and Saxifraga tridactylites L.

Cuscuta campestris Yunck.

Convolvulaceae-Therophyta parasitica-North, Central and South America-Neophyte Change of status for Umbria: from casual alien to naturalized alien

Notes-Cuscuta campestris was reported as an invasive or naturalized alien for many Italian regions (but absent in Basilicata). Only in Umbria was it indicated as casual [34,73]. However, on the basis of a stabilized population recently monitored in the urbanized area of Spello, we propose the status of naturalized in Umbria for this species.

Cyperus difformis L.

Cyperaceae-Therophyta caespitosa-Africa, Europa (?) and South Asia-Neophyte Change of status for Toscana: from casual alien to naturalized alien

Notes-This species is a typical weed of rice fields [28] and occurs in many Italian regions [34]. We found it abundantly colonizing rice fields and adjacent channels South of Siena. We thus propose to change its status in Toscana from casual to naturalized alien.

\section{Cyperus rotundus $\mathrm{L}$.}

Cyperaceae-Geophyta rhizomatosa-Subcosmopolitan (?)

Change of status for Calabria: from naturalized alien to cryptogenic

Notes-Cyperus rotundus is a geophyte weed readily propagating vegetatively, with uncertain origin, and by now with a subcosmopolitan distribution [111]. In Italy, it grows in anthropogenic places including cultivated fields [28]. As its presence is related to human activities, its native range is difficult to define today. It is considered as alien in northern Italy and Calabria, while in other Italian regions it is classified as cryptogenic $[33,66]$. Pending further studies on the chorology of this species, in Calabria it should be considered as cryptogenic, consistent with neighboring regions. In this region, it is widespread in fields and anthropogenic environments, especially in coastal areas (e.g., Melia di Scilla and Reggio Calabria).

Dactyloctenium aegyptium (L.) Willd.

Poaceae-Therophyta scaposa-Africa and South Asia-Neophyte Change of status for Calabria: from naturalized alien to invasive alien

Notes-The annual herb Dactyloctenium aegyptium in Italy is currently reported as casual for Campania (where it is known in just two sites [93]), and as naturalized for Lazio, Calabria, Sicilia and Sardegna [34]. However, based on our findings and observations carried out in Calabria (i.e., Brancaleone, Nocera Terinese, Reggio Calabria, Ricadi, and Sellia Marina), it forms true grass carpets on sandy and rocky beaches and grows along sidewalks and roadsides. It spreads very rapidly in such environments and should thus be considered invasive in the region. Particularly, it tends to invade the coastal dunes with habitats 2110 (embryonic shifting dunes), 2120 (shifting dunes along the shoreline with Ammophila arenaria (white dunes)) and 2230 (Malcolmietalia dune grasslands). In these plant communities D. aegyptium competes with many native species such as Cakile maritima Scop. subsp. maritima, Calamagrostis arenaria (L.) Roth subsp. arundinacea (Husn.) Banfi, Galasso \& Bartolucci, Centaurea sphaerocephala L. subsp. sphaerocephala, Convolvulus soldanella L., Euphorbia peplis L., Matthiola tricuspidata (L.) W.T.Aiton, Medicago marina L., Pancratium maritimum L. and Polygonum maritimum L.

\section{Datura inoxia Mill.}

Solanaceae-Therophyta scaposa-North, Central and South America-Neophyte Change of status for Calabria: from casual alien to naturalized alien

Notes-Datura inoxia is an American therophyte, sometimes cultivated as an ornamental plant in Italy [30]. It was recorded often as casual from many Italian regions except for Valle d'Aosta, Trentino-Alto Adige, Liguria and Umbria [34]. The new findings here reported (i.e., Bova Marina, Condofuri, San Lorenzo, Sellia Marina, and Trebisacce), show 
populations stabilized for many years and self-maintaining. Therefore, the species can be considered naturalized for the region.

\section{Datura stramonium L.}

Solanaceae-Therophyta scaposa-North and Central America-Neophyte Change of status for Calabria: from naturalized alien to invasive alien

Notes-Native to North and Central America, Datura stramonium is widespread in all Italian regions and in many of these it is reported as invasive [34]. In Calabria (i.e., Melito di Porto Salvo, Reggio Calabria, San Lorenzo, San Roberto, and Scilla), this species occupies both urbanized and non-urbanized areas, and is increasingly expanding its range from year to year thanks to its abundant production of seeds. For this reason, D. stramonium should be considered invasive for the region.

\section{Delphinium hispanicum Willk. ex Costa}

Ranunculaceae-Therophyta scaposa-Eurasian-Neophyte

First geolocalized reports in Puglia (naturalized alien)

Notes-Delphinium hispanicum was first reported from Puglia by Galasso et al. [34] sub D. orientale J.Gay based on our unpublished records. In Table S1, we provide full details concerning these discoveries (Mattinata and Monte Sant'Angelo).

Deschampsia cespitosa (L.) P.Beauv. subsp. parviflora (Thuill.) Dumort.

Poaceae-Hemicryptophyta caespitosa-Eurasian

First record for Abruzzo (native)

Notes-Deschampsia cespitosa subsp. parviflora was previously reported in Italy only for Piemonte, Lombardia, Toscana and Calabria [33,62,63]. Like in UK [112], this taxon is probably under-recorded in Italy. In Abruzzo, a population with several tens of individuals, in an area of about two hectares whithin a mixed forest with Quercus cerris L. and Fagus sylvatica L. subsp. sylvatica, was recently found. Specimens were identified with Tison and De Foucault [99] and Pignatti et al. [28].

\section{Digitaria ciliaris (Retz.) Koeler}

Poaceae-Therophyta scaposa-Africa and South Asia-Neophyte Change of status for Calabria: from naturalized alien to invasive alien

Notes-Digitaria ciliaris, an annual herb very similar to Digitaria sanguinalis (L.) Scop. [113], is reported as a naturalized or casual alien for all Italian regions, except Valle d'Aosta, Marche and Puglia [34,71]. Wilhalm [113] reported this species for Calabria and then Galasso et al. [71] updated its status as naturalized for this region. However, due to several new finds and observations for the region and according to its capacity to easily spread and invade new sites (i.e., Bagnara Calabra, Melia di Scilla, Montebello Jonico, Reggio Calabria, and San Lorenzo), this species should be considered invasive for the region.

\section{Drymochloa drymeja (Mert. \& W.D.J.Koch) Holub subsp. exaltata (C.Presl) Foggi \& Signorini \\ Poaceae-Geophyta rhizomatosa-Italian endemic New distribution data for Italian rare species in Lazio (native)}

Notes-Current distribution range of Italian endemic Drymochloa drymeja subsp. exaltata includes central-southern Italy and Sicilia [33]. Here, it is considered diagnostic for beech and ravine forests in southern Italy $[114,115]$. In Lazio D. drymeja subsp. exaltata was known for only two sites: Insugherata Nature Reserve (Monte Arsiccio) in the center of Rome, and the San Vittorino gorge on the outskirts of Roma in the municipality of Tivoli $[90,116]$. However, Foggi et al. [117] in a recent review on Festuca and allied genera have identified the specimens from San Vittorino and from Monte Arsiccio as D. sylvatica (Pollich) Holub, a species with central European distribution. The conclusions of these authors would suggest exclusion of this taxon from the regional flora. However, two specimens from the San Vittorino deposited in APP and HFLA respectively, were both recently confirmed by us as $D$. drymeja subsp. exaltata. Additionally, our recent discovery 
on Monte Petrella, located within the Natural Park of Monti Aurunci in southern Lazio, confirms the presence of this endemic in the region. Festuca s.l. is a very complex group and obviously this situation of uncertainty in the location of the Lazio samples will require further analysis, especially because the northernmost limit of D. drymeia subsp. exaltata in the Italian Peninsula runs precisely between Lazio and Abruzzo. However, the reporting of this taxon for the Monti Aurunci is considered important because it covers a gap in the Tyrrhenian side of peninsular Italy where the northernmost stations before those of Lazio are located on the Piana Campana [118] and in the Bay of Napoli [88,89,119].

\section{Echinochloa hispidula (Retz.) Nees}

Poaceae-Therophyta scaposa-Asia-Neophyte

First record for Toscana (casual alien)

Notes-This Asian species is naturalized across northern Italy [34], where it grows as a weed in rice fields [28]. In SIENA, we found an unpublished sample of this species collected in 1989 in crop fields near Carrara, and thus report this exotic as casual for Toscana for the first time.

Elaeagnus $\times$ submacrophylla Servett.

Eleagnaceae-Nano-Phanerophyta-Japan and Korea-Neophyte

First record for Toscana (casual alien)

Notes-Elaeagnus $\times$ submacrophylla, a hybrid of Elaeagnus macrophylla Thunb. and Elaeagnus pungens Thunb. widely cultivated as an ornamental plant for hedges, was reported in Italy as casual for Piemonte, Abruzzo and Campania [34]. A few individuals, probably spread by seeds from plants cultivated nearby, were recently found in a riparian shrubland near the city centere of Monteroni d'Arbia in Toscana.

Elaeodendron croceum (Thunb.) DC.

Celastraceae-Phanerophyta caespitosa-South Africa-Neophyte

First record for Europe (casual alien)

First record for Sardegna (casual alien)

Notes-Elaeodendron croceum is an evergreen tree native to South Africa, sometimes cultivated in Italy as an ornamental plant (A. Stinca, pers. comm.). A small population of this neophyte was observed in anthropogenic environments in Sardegna (Cagliari). These individuals had spread by seed from plants cultivated nearby. As far as we know, these are the first find in Europe. For the nomenclature, we followed POWO [120].

\section{Eleusine indica (L.) Gaertn.}

Poaceae-Therophyta scaposa-Africa, South Asia and North Oceania-Neophyte Change of status for Toscana: from naturalized alien to invasive alien

Notes-This synanthropic grass is considered invasive in several regions of Italy [34]. In Toscana, it was considered naturalized [34], though abundant and widespread in ruderal sites during summer. The species is present throughout the city of Siena, where it mainly colonizes sidewalks and urban pavements. We propose to change its status from naturalized to invasive in the region.

\section{Eruca vesicaria (L.) Cav.}

Brassicaceae-Therophyta scaposa-Mediterranean (?) and Asian

Change of status for Calabria: from naturalized alien to cryptogenic

Notes-Eruca vesicaria is a therophyte with an uncertain area of origin, which in Italy is also cultivated as a vegetable [29]. It is considered as alien in some northern Italian regions and Calabria, while in other regions it is classified as cryptogenic [33]. Pending further studies on the chorology of this species, in Calabria it should be considered as cryptogenic, consistent with neighboring regions. In this region, it is widespread in fields and anthropogenic environments (i.e., Maierato, Montebello Jonico, and Reggio Calabria). 


\section{Erythrostemon gilliesii (Wall. ex Hook.) Klotzsch}

Fabaceae-Phanerophyta caespitosa-South America-Neophyte

First record for Umbria (casual alien)

Notes-Shrub native to South America, Erythrostemon gilliesii is sometimes cultivated as ornamental plant in Italy (A. Stinca, pers. comm.). It was recorded as casual for Toscana, Lazio, Calabria and Sardegna, while only in Sicilia was it indicated as naturalized [34,72]. Therefore, our recent discovery in Spello is the first in Umbria and concerns a few plants spread by seed.

\section{Euphorbia cuneifolia Guss.}

Euphorbiaceae-Therophyta scaposa-West Mediterranean

First geolocalized reports in Puglia (native)

Notes-Euphorbia cuneifolia is an uncommon therophyte in Italy reported for Toscana, Lazio, Molise, Campania, Puglia, Calabria, Sicilia and Sardegna [33]. It was first indicated from Puglia by Bartolucci et al. [33] based on our unpublished record. In Table S1 we provide full details concerning this discovery (Monte Sant'Angelo).

\section{Euphorbia maculata L.}

Euphorbiaceae-Therophyta scaposa-North and Central America-Neophyte Change of status for Calabria: from naturalized alien to invasive alien

Notes-Euphorbia maculata was reported as an invasive or naturalized alien for all Italian regions $[34,73,121]$. In Calabria, where it was considered naturalized, this species is very widespread in dry and nitrophilous environments (i.e., Melito Porto Salvo, Reggio Calabria, and Sellia Marina) and shows a high capacity to spread by seed. It should be considered invasive for the region, as in many other Italian regions.

\section{Euphorbia prostrata Aiton}

Euphorbiaceae-Therophyta scaposa-North, Central and South America-Neophyte Change of status for Umbria: from casual alien to naturalized alien

Notes-Euphorbia prostrata is reported as an invasive or naturalized alien for all Italian regions; only in Umbria was it indicated as casual $[34,73,121]$. However, based on two stabilized populations recently monitored in urbanized areas of Foligno and Spello, we propose the status of naturalized in Umbria for this species.

\section{Ficus microcarpa L.f.}

Moraceae-Phanerophyta scaposa—South-East Asia and Australia—Neophyte Change of status for Calabria: from casual alien to naturalized alien

Notes-Musarella et al. [122] reported this species as casual for Calabria. However, since we recently observed that it is very widespread along roadsides and cracks of walls and maintaining its individuals for many years (i.e., Reggio Calabria and Villa San Giovanni), it can be considered naturalized for the region.

Galium lucidum All. subsp. lucidum

Rubiaceae-Hemicryptophyta scaposa-Euri-Mediterranean

First record for Puglia (native)

Notes-Galium lucidum subsp. lucidum is reported from all Italian regions except Lazio, Molise, Puglia, Basilicata and Sardegna [33]. Here, we provide the first records of this taxon for Puglia, all from the Gargano promontory, see also [123].

Gladiolus italicus Mill.

Iridaceae-Geophyta bulbosa-Mediterranean area (?) and South-West Asian Change of status for Calabria: from naturalized alien to cryptogenic

Notes-Gladiolus italicus is a geophyte sometimes confused with similar species, such as Gladiolus byzantinus Mill. (A. Stinca, pers. comm.). As its presence is related to human activities, its native range is difficult to define today. It is considered as alien in some northern Italian regions and Calabria, while in other regions it is classified as cryptogenic [33]. 
Pending further studies on the chorology of this species, in Calabria it should be considered as cryptogenic, consistent with neighboring regions. In accordance with Fanfarillo et al. [124], in Calabria it generally grows in cultivated fields (i.e., Brancaleone, Condofuri, Montebello Jonico, Reggio Calabria, and San Lorenzo).

Hydrangea macrophylla (Thunb.) Ser.

Hydrangeaceae-Nano-Phanerophyta-Japan-Neophyte

First record for Campania (casual alien)

Notes-The Japanese Hydrangea macrophylla is a very common ornamental plant in Italy (A. Stinca, pers. comm.). Previously recorded as a casual alien from Piemonte, Trentino-Alto Adige, Veneto and Toscana, and as naturalized only in Toscana [34,73]. Therefore, our recent discovery in Vico Equense is the first in Campania and concerns a few plants spread by seed.

Hypericum $\times$ inodorum Mill.

Hypericaceae-Nano-Phanerophyta—South and West European

First record for Marche (native)

Notes-This taxon is not reported in the checklist of the vascular flora native to Italy [33] because it is a hybrid between Hypericum androsaemum L. and Hypericum hircinum L. In Italy, it was indicated only for Campania in the Sorrento Peninsula [125]. Therefore, our recent discovery in Cagli is the first in Marche. For the nomenclature, we followed POWO [126].

Impatiens balfourii Hook.f.

Balsaminaceae-Therophyta scaposa-South Asia-Neophyte

Change of status for Lazio: from casual alien to naturalized alien

Notes-This species was recorded for several localities in Lazio [96] and indicated as a casual alien by Galasso et al. [34]. In Alatri in Lazio where we collected it, the species has certainly been present since at least 2008 (see Google Street images https:/ /www.google.it/maps/dir/ Via+Campo+le+Fraschette,+03011+Alatri+FR/@41.7297813,13.3153171,64m/data=!3m1!1e3 !4m9!4m8!1m0!1m5!1m1!1s0x132559a97f3e015d:0x46a9f6d11bfa41c8!2m2!1d13.3155165!2d41. 7298483!3e3"\t"\_blank"https:/ /www.google.it/maps/dir//Via+Campo+le+Fraschette,+030 11+Alatri+FR/@41.7297813,13.3153171,64m/data=!3m1!1e3!4m9!4m8!1m0!1m5!1m1!1s0x132 559a97f3e015d:0x46a9f6d11bfa41c8!2m2!1d13.3155165!2d41.7298483!3e3, accessed on 15 September 2021). We thus propose to consider it as naturalized in the region.

Ipomoea indica (Burm.) Merr.

Convolvulaceae-Geophyta rhizomatosa-North, Central and South America-Neophyte Change of status for Calabria: from naturalized alien to invasive alien

Notes-Ipomoea indica is an American geophyte, in Italy often cultivated as an ornamental plant (A. Stinca, pers. comm.). Galasso et al. [34] reported this neophyte as naturalized for Calabria. However, since this species is very widespread in anthropogenic environments (i.e., Calanna, Reggio Calabria, and Villa San Giovanni) and shows a high capacity to invade new sites, it should be considered invasive for the region.

\section{Ipomoea purpurea (L.) Roth}

Convolvulaceae-Therophyta scaposa-North, Central and South America-Neophyte Change of status for Lazio: from casual alien to naturalized alien

Change of status for Basilicata: from invasive alien to naturalized alien

Change of status for Calabria: from casual alien to naturalized alien

Notes-Galasso et al. [34,69] reported this alien therophyte for all Italian regions, but only in Basilicata as invasive. Effectively, in this region Ipomoea purpurea was previously recorded as an invasive alien for Maratea [127]. The presence of this taxon in the region was also reported in the Forum Acta Plantarum (https: / /www.floraitaliae.actaplantarum. org/viewtopic.php?t=115754, accessed on 2 September 2021) for Pisticci, but not officially published. Our recent field investigations revealed the sporadic presence of this species in Basilicata, where it does not show invasive characteristics. Therefore, this species should be 
considered naturalized in Basilicata. Additionally, in Lazio and Calabria this exotic shows stabilized populations and should be considered naturalized.

Isatis tinctoria L. subsp. tinctoria

Brassicaceae-Hemicryptophyta biennia-South-East Europe-Archaeophyte

Change of status for Calabria: from naturalized alien to invasive alien

Notes-This taxon is reported as an invasive or naturalized alien for all Italian regions, except in Friuli-Venezia Giulia where is indicated as casual [34]. However, due to several records and observations in the field of this species (i.e., Bova, Cardeto, and Reggio Calabria), it should be considered invasive also in this region.

\section{Juglans nigra $\mathrm{L}$.}

Juglandaceae-Phanerophyta scaposa-North America-Neophyte

First record for Toscana (casual alien)

Notes-Juglans nigra is cultivated for economic purposes in Italy, and it is established in the wild in several regions as a casual to invasive alien $[34,69,70]$. In Toscana, we found some spontaneous young individuals growing in a riparian shrubland near a plantation along the Fiume Arbia at Castelnuovo di Berardenga, near Siena.

\section{Juglans regia L.}

Juglandaceae-Phanerophyta scaposa-South-West Asia-Neophyte (cryptogenic?)

First record for Puglia (casual alien)

Change of status for Calabria: from casual alien to naturalized alien

Notes-Juglans regia is a South-West Asian tree, in Italy often cultivated for its appreciated fruits [29]. Is it recorded as cryptogenic in Lombardia, Veneto and Sardegna, and as casual or naturalized from many Italian regions except for Puglia [33,65]. In this region, some small populations of young individuals spread by seed from plants cultivated nearby were observed in anthropogenic environments. In Calabria, although this species was considered casual by Laface et al. [101], recent field observations revealed that this exotic shows stabilized populations and should be considered as naturalized.

Kalanchoë blossfeldiana Poelln.

Crassulaceae-Hemicryptophyta succulenta-Madagascar-Neophyte

First record for Europe (casual alien)

First record for Sardegna (casual alien)

Notes-Kalanchoë blossfeldiana is a perennial succulent native to Madagascar, very popular in Italy as an ornamental plant (A. Stinca, pers. comm.). A single individual of this neophyte, growing together with Oxalis latifolia Kunth, was observed in an anthropogenic environment in Sardegna (Cagliari). It probably originated from vegetative parts of plants cultivated in pots. As far as we know, this was the first finding in Europe.

\section{Kalanchoë daigremontiana Raym.-Hamet \& H.Perrier}

Crassulaceae-Chamaephyta succulenta-Madagascar-Neophyte

Exclusion for Calabria (naturalized alien)

Notes-The revision of the specimens preserved in FI concerning the only reports of Kalanchoë daigremontiana for Calabria (i.e., Caraffa del Bianco, Catanzaro, and Scalea [128]) led to the exclusion of this species from the regional flora, attributing the relative findings to Kalanchoë $\times$ houghtonii D.B.Ward. According to Stinca et al. [129] it is probable that many of the Italian reports of $K$. daigremontiana are erroneous and should be allocated to K. $\times$ houghtonii (see below note).

Kalanchoë delagoënsis Eckl. \& Zeyh.

Crassulaceae-Chamaephyta succulenta-Madagascar-Neophyte

First record for Campania (casual alien)

Notes-Kalanchoë delagoënsis, endemic to Madagascar, is an uncommon ornamental plant in Italy (A. Stinca, pers. comm.). Here, it was recorded as casual in Lazio, Puglia, 
Calabria, Sicilia and Sardegna [34,72]. In Campania, we discovered two small populations of this neophyte in the urban area of Caserta, undoubtedly spread by plantlets produced at the margins of leaves of nearby cultivated plants.

\section{Kalanchoë $\times$ houghtonii D.B.Ward}

Crassulaceae-Chamaephyta succulenta-Artificial origin-Neophyte

Change of status for Calabria: from naturalized alien to invasive alien

Notes-Kalanchö $\times$ houghtonii, an artificial hybrid created in the 1930s in the USA by experimental crossings between Kalanchoë daigremontiana and Kalanchoë delagoënsis, is one of the most rapidly expanding invasive plants in recent times [130]. It was recently indicated as naturalized in Calabria by Stinca et al. [129]. Recent new field observations revealed that this exotic grows abundantly on the roofs of old abandoned houses, in dry stone walls, in drainage ditches and along roadsides (i.e., Reggio Calabria, Scilla, Sellia Marina, and Villa San Giovanni). Therefore, this species should be considered invasive for the region.

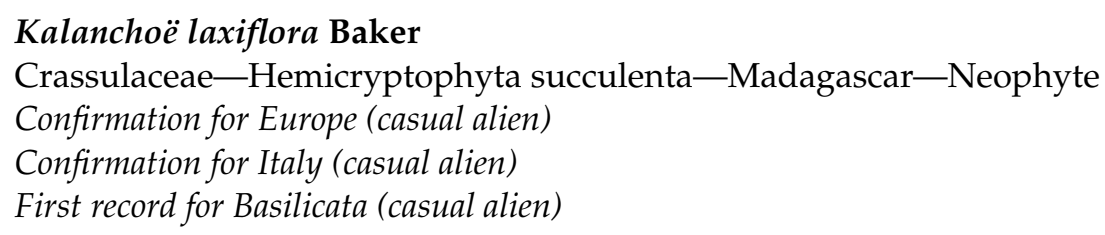

Notes-Kalanchoë laxiflora is a perennial succulent native to Madagascar, rarely cultivated in Italy (A. Stinca, pers. comm.). A small population of three young individuals of this neophyte was observed in anthropogenic environments in Basilicata (Maratea). These individuals are likely to have spread by seed from plants growing nearby. Until this record in Italy (i.e., Toscana and Sicilia), it was indicated as doubtful [34]. Therefore, our recent finding confirms the presence as a casual alien of this neophyte for Italian vascular flora. As far as we know, our finding confirms the presence of this species also in Europe.

\section{Lamarckia aurea (L.) Moench}

Poaceae-Therophyta scaposa-Mediterranean-Turanian

First geolocalized reports in Campania (native)

Notes-Lamarckia aurea is an uncommon therophyte in Italy reported for Liguria, Toscana, Lazio, Abruzzo, Molise, Campania, Puglia, Basilicata, Calabria, Sicilia and Sardegna [33]. It was historically reported from Campania only at Naples by Tenore (sub Chrysurus cynosuroides [131], sub Chrysurus cynosuroides [132], sub Chrysurus aureus [133]). Recently, only Bartolucci et al. [33] mentions this species as present in Campania without adding further details. Here, we provide the first geolocalized report of our discovery in June 2021 of a small population of this species that grows in the historic center of Naples, confirming Tenore's data.

\section{Lantana camara L. subsp. aculeata (L.) R.W.Sanders}

Verbenaceae-Nano-Phanerophyta—North and Central America-Neophyte Change of status for Calabria: from casual alien to naturalized alien

Notes-This taxon was recently indicated as casual in Calabria by Stinca et al. [129] Recent new field observations revealed that this exotic plant forms numerous populations capable of reproducing and maintaining in the surrounding territories, preferring in particular roadsides and drainage channels (i.e., Bagnara Calabra, Montebello Jonico, Reggio Calabria, San Lorenzo, and Villa San Giovanni). Therefore, the species can be considered as naturalized for Calabria.

Lepidium virginicum L. subsp. virginicum

Brassicaceae-Therophyta scaposa-North and Central America-Neophyte Change of status for Umbria: from casual alien to naturalized alien

Notes-Lepidium virginicum subsp. virginicum was reported as an invasive or naturalized alien for many Italian regions; only in Umbria and Puglia was it indicated as 
casual [34]. However, based on stabilized populations recently monitored in urbanized areas of Spello, we propose the status of naturalized in Umbria for this species.

Leucaena leucocephala (Lam.) de Wit subsp. glabrata (Rose) Zárate

Fabaceae-Phanerophyta scaposa-North and Central America-Neophyte

Change of status for Calabria: from casual alien to naturalized alien

Notes-This taxon was first reported for Calabria as casual by Musarella et al. [122]. However, other new spreading sites have since been found (i.e., Reggio Calabria, Roccaforte del Greco, and Sellia Marina). The species prefers roadsides and sidewalks and easily germinates from the numerous dispersed seeds. Many adult individuals at different stages of growth, with inflorescences and ripe fruits, are found at new and old record sites, producing several seedlings. Therefore, the species can be considered naturalized for Calabria.

\section{Ligustrum lucidum W.T.Aiton}

Oleaceae-Phanerophyta scaposa-South-East Asia-Neophyte

Change of status for Calabria: from casual alien to naturalized alien

Notes-First reported as casual by Galasso et al. [134] for the province of Cosenza, in the northern part of Calabria, now Ligustrum lucidum was found in new stations in the southern part (i.e., Reggio Calabria, San Roberto, and Villa San Giovanni), growing along the roadsides and easily germinating from dispersed seeds. Some adult individuals at different stages of growth were found in the new site records, producing seedlings. Therefore, L. lucidum can be considered naturalized for Calabria.

\section{Melia azedarach $\mathrm{L}$.}

Meliaceae-Phanerophyta scaposa-South-East Asia and Australia-Neophyte Change of status for Calabria: from casual alien to naturalized alien

Notes-Reported for the first time for the region as casual for the provinces of Cosenza and Reggio Calabria [135], this species was found in new stations and, in the latter, growing along roadsides and sidewalks and easily germinating from dispersed seeds (i.e., Bagnara Calabra, Melito di Porto Salvo, and Reggio Calabria). Numerous adult individuals at different growth stages were found at the new collection sites, capable of producing new seedlings. Therefore, the species can be considered naturalized for Calabria.

\section{Morus nigra $\mathbf{L}$.}

Moraceae-Phanerophyta scaposa-South-West Asia-Archaeophyte Change of status for Calabria: from casual alien to naturalized alien

Notes-Morus nigra is an Asian deciduous tree often cultivated in Italy for its sorosis [29]. According to Galasso et al. [34], in Italy it was reported as a casual alien for many regions, including Calabria. At present, in the different populations found (i.e., Reggio Calabria and Scilla), individuals were born in the vicinity of mature trees and created populations with adult plants, some of which reproduced. Therefore, the species can be considered naturalized in this region.

\section{Nephrolepis cordifolia (L.) C.Presl}

Nephrolepidaceae-Geophyta rhizomatosa—South-East Asia and Australia-Neophyte Change of status for Calabria: from casual alien to naturalized alien

Notes-Nephrolepis cordifolia is a commonly cultivated fern in Italy (A. Stinca, pers. comm.), but reported as naturalized for Liguria, Toscana, Lazio and Campania, while in Marche, Abruzzo, Calabria, Sicilia and Sardegna it is indicated as casual [34,73]. However, based on a stabilized population recently monitored in an urbanized area of the old town of Verbicaro, we propose the status of naturalized in Calabria for this species.

\section{Nicotiana glauca Graham}

Solanaceae-Nano-Phanerophyta-South America-Neophyte

Change of status for Puglia: from invasive alien to naturalized alien 
Notes-The South American phanerophyte Nicotiana glauca is recorded from many Italian regions, but only in Puglia, Calabria, Sicilia and Sardegna is it reported as invasive [34,69]. However, in Puglia, although it is stabilized in some coastal areas from Barletta to Salento where it grows occasionally with a few individuals, it does not show invasive characteristics. Based on our field observations, we thus propose the status of naturalized in Puglia for this species.

\section{Nothoscordum gracile (Aiton) Stearn \\ Amaryllidaceae-Geophyta bulbosa-Central and South America-Neophyte Change of status for Sardegna: from casual alien to naturalized alien}

Notes-Nothoscordum gracile is reported as casual, naturalized, or invasive for some Italian regions [34,71,72]. In Sardegna, it occurs widely in different parts of the city of Cagliari and in apparent expansion, in the cracks of sidewalks, at the base of walls and along streets. It forms populations capable of reproducing through seeds even in the absence of plants cultivated nearby. Many of the reports for Sardinia of Nothoscordum borbonicum Kunth could be attributed to $N$. gracile.

Ophrys dinarica Kranjčev \& P.Delforge

Orchidaceae-Geophyta bulbosa-Amphi-Adriatic

First geolocalized reports in Molise (native)

Notes-Bartolucci et al. $[33,66]$ report Ophrys dinarica from Valle d'Aosta, Piemonte and Lombardia to Molise region, the latter region being the southernmost limit of distribution of this taxon in Italy. However, the occurrence of this species in Molise is reported only generically in books [136] or as a general synthesis, without providing indications of collection sites or images of the plants collected [137]. Here, we provide the first geolocalized report of our discovery in June 2020 of a population of this species that grows in Capracotta.

Opuntia dillenii (Ker Gawl.) Haw.

Cactaceae-Nano-Phanerophyta succulenta-North and Central America-Neophyte First record for Marche (naturalized alien)

Notes-On Italian territory, Opuntia dillenii was recorded in Toscana, Lazio, Campania, Puglia, Calabria, Sicilia and Sardegna [34]. During fieldwork, we found two new populations also in Cagli in the Marche region. In the area of Acquaviva, the species was introduced for ornamental purposes in the early 1970s (G. Mei, pers. comm.). From the plant introduced initially, the species reproduced abundantly vegetatively, expanding until it became a problem for the owners themselves. Despite a series of interventions aimed at containing the species, these have nevertheless only managed to limit its expansion within the garden area while the species, albeit very slowly, continues to expand in the immediately adjacent areas. The population present in $\mathrm{Ca}^{\prime}$ Giovanni, originating in all probability from the remains of shovels thrown on the ground, is located near the road at the beginning of the town where it characterizes an area of about $20 \mathrm{~m}^{2}$ of vegetation typical of abandoned land, featuring Prunus spinosa L. subsp. spinosa and Rubus ulmifolius Schott. From a phytosociological point of view, both the find areas can be traced back to the Pruno spinosae-Rubion ulmifolii O.Bolòs 1954 alliance. It is also interesting to note that in the population present in Acquaviva, sunnier and less exposed to humidity, in the last two years the emergence of seedlings has been observed which do not survive the winter.

Opuntia ficus-indica (L.) Mill.

Cactaceae-Phanerophyta succulenta-North America-Neophyte

Change of status for Basilicata: from naturalized alien to invasive alien

Notes-Opuntia ficus-indica, a phanerophyte native to North America, has been reported for almost all Italian regions except for Valle d'Aosta, Piemonte, Veneto and FriuliVenezia Giulia [34]. Indicated as invasive throughout southern Italy, it is considered naturalized only in Basilicata. However, especially in the Matera municipality, this species is rapidly colonizing many of the rocky slopes of the Regional Park of Murgia Materana 
and the Bradano gorge (Gravina del Bradano). Therefore, we propose the status of invasive in Basilicata for this neophyte.

Oryza sativa L. subsp. sativa

Poaceae-Therophyta scaposa-China-Archaeophyte

Change of status for Toscana: from casual alien to naturalized alien

Notes-This taxon occurs as a casual to invasive species in the northern Italian regions where it is cultivated as a crop [34]. In Toscana, where some rice fields are present in the South of the region, it was considered as a casual alien. In Murlo we found conspicuous populations growing in channels and pebbly shores around rice fields. Thus, we propose to change its status from casual to naturalized in Toscana.

Oxalis brasiliensis Lodd., G.Lodd. \& W.Lodd. ex Drapiez

Oxalidaceae-Geophyta bulbosa-South America-Neophyte

First record for Europe (historical record for casual alien)

First record for Italy (historical record for casual alien)

First record for Toscana (historical record for casual alien)

Notes-Oxalis brasiliensis is a geophyte native to Argentina, Uruguay and Brazil, and also reported as an alien in the state of Alabama in the USA [138]. Its presence as an alien species in Europe (Italy, Toscana) is only certified by specimens (sub Oxalis macachin Arechav.) traced in FI and collected by Rodolfo Pichi Sermolli on 1935 and 1936. Pichi Sermolli, in his handwritten notes, states that this species was also spontaneous at Poggio Imperiale in Firenze, in addition to Buggiano. Nowadays, this neophyte no longer seems to be present in nature in Italy despite our field research (A. Stinca and G. Ferretti, pers. comm.). Therefore, it should be added to the European and Italian vascular flora as a taxon not recently confirmed. The species was firstly described by Drapiez [139], who predates Hildebrand [140]; unlike what is reported by IPNI [141] and POWO [142], Drapiez's reference to Loddiges is to be referred to the whole Loddiges family, that is Conrad Loddiges and Sons, namely Lodd. (i.e., Joachim Conrad Loddiges), G.Lodd. (i.e., George Loddiges) and W.Lodd. (i.e., William Loddiges) [143].

Oxalis debilis Kunth

Oxalidaceae-Geophyta bulbosa-Central and South America-Neophyte

First record for Friuli-Venezia Giulia (casual alien)

First record for Umbria (casual alien)

Notes-Oxalis debilis is recorded as a naturalized alien from Piemonte, Lombardia, Veneto, Liguria, Emilia-Romagna, Toscana, Abruzzo and Campania, while in Lazio, Calabria, Sicilia and Sardegna it is reported as a casual alien [34,69,71,73]. Furthermore, in Marche its invasion status is undefined, while it is doubtful in [34]. Therefore, our findings in Trieste and Assisi represent the first for Friuli-Venezia Giulia and Umbria, respectively.

Oxalis dillenii Jacq.

Oxalidaceae-Hemicryptophyta/Therophyta scaposa-North America-Neophyte Confirmation for Campania (casual alien)

Notes-Oxalis dillenii is a North American herb introduced in Italy, but here it is often confused with similar species, that is Oxalis corniculata L. and Oxalis stricta L. [144]. Due to identification difficulties, the data on its Italian distribution are still lacking. Since no pertinent samples were found in Italian herbaria (A. Stinca, pers. comm.), in Campania it was indicated as a doubtful [34]. Therefore, our recent find in the anthropogenic environments of Caserta and Salerno confirms its presence as a casual alien in the region.

\section{Oxalis latifolia Kunth}

Oxalidaceae-Geophyta bulbosa-North, Central and South America-Neophyte Change of status for Calabria: from casual alien to naturalized alien

Notes-Oxalis latifolia is an American geophyte introduced into Italy, but here often confused with similar species, such as Oxalis articulata Savigny [144]. This neophyte is 
recorded as a casual or naturalized alien from many Italian regions except for Valle d'Aosta, Molise; instead, in Friuli-Venezia Giulia and Marche its presence is doubtful [34,73]. In Calabria, Oxalis latifolia was recently recorded as a casual alien by Rosati et al. [41]. However, the indicated status is incorrect as this species is clearly naturalized in the region, as indicated by Rosati et al. [41] who define it as "abundantly naturalized".

Oxalis pes-caprae L.

Oxalidaceae-Geophyta bulbosa-South Africa-Neophyte

First record for Veneto (casual alien)

Notes-Oxalis pes-caprae, a geophyte native to South Africa, after its introduction in the eighteenth century, has become one of the most widespread in the Mediterranean basin [144]. Indeed, it is recorded often as invasive by many Italian regions except for Valle d'Aosta, Veneto and Friuli-Venezia Giulia [34]. Therefore, our finding in Padova represents the first for Veneto.

Papaver rhoeas L. subsp. rhoeas

Papaveraceae-Therophyta scaposa-East-Mediterranean area (?)

Change of status for Calabria: from naturalized alien to cryptogenic

Notes-Papaver rhoeas subsp. rhoeas is an annual weed readily propagating by seeds, perhaps originally from the eastern Mediterranean, but by now with a subcosmopolitan distribution [145]. In Italy, it grows in anthropogenic places including cultivated fields [124]. As its presence is related to human activities, its native range is difficult to define today. It is considered as an alien in some northern Italian regions and in Calabria, while in other regions it is classified as cryptogenic [33]. Pending further studies on the chorology of this species, in Calabria it should be considered as cryptogenic, consistent with neighboring regions. In this region, it is widespread in fields and anthropogenic environments, especially in coastal areas (e.g., Melito di Porto Salvo, Montebello Jonico, Motta San Giovanni, Reggio Calabria, San Ferdinando, San Lorenzo, Serrastretta, and Villa San Giovanni).

Parthenocissus inserta (A.Kern.) Fritsch

Vitaceae-Phanerophyta lianosa-North America-Neophyte

First record for Umbria (naturalized alien)

First record for Calabria (casual alien)

First record for Campania (naturalized alien)

Notes-Parthenocissus inserta is a liana native to North America often cultivated as an ornamental plant in Italy [29]. It is a doubtful taxon and very similar to Parthenocissus quinquefolia (L.) Planch. (in the past it was also considered a heterotypic synonym) from which it is mainly distinguished by the type of inflorescence (compound dichasium without distinct central axis vs. paniculate polychasium with a well-developed main axis) and tendrils (usually without adhesive discs vs. with adhesive discs) $[146,147]$. Due to identification difficulties, the data on its Italian distribution are still missing. Currently, in Italy it is reported as invasive in Lombardia and Veneto, as naturalized in Emilia-Romagna, and as casual in Toscana and Marche [34,72]. In Umbria, a large population was recently discovered along Fiume Topino in Foligno and it appears stabilized. The revision of the specimens preserved in PORUN-Herb. Stinca (linked to Stinca and Motti [89], Motti and Stinca [148] and Stinca et al. [149]) and PI (http:/ /jacq.org/detail.php?ID=1737273, accessed on 6 August 2021), all previously identified as Parthenocissus quinquefolia, led the species Parthenocissus inserta to be added to the flora of Campania (Figure 2E) and Calabria.

Parthenocissus tricuspidata (Siebold \& Zucc.) Planch.

Vitaceae-Phanerophyta lianosa-South-East Asia-Neophyte

First record for Calabria (casual alien)

Notes-This species is native to South-East Asia and often cultivated in Italy as an ornamental plant [29]. It is recorded as a casual or naturalized alien in many Italian regions except Valle d'Aosta, Abruzzo, Molise, Calabria and Sardegna [34,69]. Therefore, our recent 
find in Bova, Scilla and Villa San Giovanni are the first in Calabria and concern a few plants spread by seed.

\section{Paspalum notatum Flüggé}

Poaceae-Hemicryptophyta caespitosa-South America-Neophyte First record for Campania (casual alien)

Notes-A hemicryptophyte native to South America, Paspalum notatum was recently reported in Italy (Calabria) by Stinca et al. [150]. Later, it was also indicated in Basilicata [41] and Emilia-Romagna [73]. A new population was discovered by us also in the southern part of Campania in the Capaccio Paestum municipality. In accordance with Stinca et al. [150], also in Campania, this alien species was probably introduced via seeds to create lawns and thus subsequently spread. The new discovery extends its southern Italian distribution northward along the Tyrrhenian coast.

\section{Persicaria lapathifolia (L.) Delarbre subsp. lapathifolia}

Polygonaceae-Therophyta scaposa-Subcosmopolitan

First record for Puglia (native)

Notes-Persicaria lapathifolia subsp. lapathifolia is reported from most regions in northern and central Italy, whereas in southern Italy it is reported only from Molise and Campania $[33,62,64]$. Here, we provide the first two records of this taxon for Puglia, both from the Gargano promontory (see also [123]).

\section{Phyllostachys aurea Carrière ex Rivière \& C.Rivière \\ Poaceae-Phanerophyta caespitosa-South-East Asia-Neophyte \\ First record for Abruzzo (casual alien) \\ First record for Molise (naturalized alien)}

Notes-Phyllostachys aurea is recorded as a casual or naturalized alien in many Italian regions, while it shows a distribution gap in the eastern side of central Italy including Marche, Abruzzo and Molise [34,69,71,72]. However, we discovered some new populations in Abruzzo (Balsorano and Teramo) and Molise (Venafro). The population of Venafro has been monitored for more than ten years. Here, the species appears stabilized tending to invade the cultivated fields bordering the roads and the drainage channels in the plain, despite the continuous cutting-back by farmers.

Phyllostachys edulis (Carrière) J.Houz.

Poaceae-Phanerophyta caespitosa—South-East Asia—Neophyte

First record for Marche (naturalized alien)

Notes-Phyllostachys edulis is found as a casual alien in various Italian regions [34]. In the Marche region, P. edulis grows wild near the Torrente Bisciugola and the Fiume Bosso (Cagli) where, starting from gardens where it was cultivated, the species spontaneously expanded along the banks areas and neighboring abandoned grasslands.

Physalis philadelphica Lam.

Solanaceae-Therophyta scaposa-North and Central America-Neophyte First record for Campania (casual alien)

Notes-This neophyte, native to North and Central America, was recently recorded as casual in Italy, based on a specimen collected in July 2018 in Lazio [69]. Therefore, our discovery in Torre del Greco in November 2017 can be considered the first for Campania but also the first discovery in Italy prior to the publication of Galasso et al. [69]. The few individuals observed in Campania were probably spread by the seeds of plants growing nearby.

\section{Phytolacca americana L.}

Phytolaccaceae-Geophyta rhizomatosa-North America-Neophyte Change of status for Calabria: from naturalized alien to invasive alien

Notes-Phytolacca americana is a North American geophyte known as aninvasive or naturalized alien in all Italian regions, except in Puglia where it is reported as casual [34]. 
In Calabria, it shows a very aggressive capacity for invading sidewalks, roadsides, railway embankments, uncultivated lands and other nitrophilous environments, where it spreads easily by dispersal of its many ripe fruits dispersed (i.e., Cardinale, Palmi, Reggio Calabria, San Roberto, and Villa San Giovanni). It was also found in the Rhamno catharticae-Prunetea spinosae Rivas Goday and Borja ex Tüxen 1962 communities close to Lago dell'Aquila [151] where it was also observed in abandoned citrus groves. Therefore, the species should be considered invasive for Calabria, as in several other Italian regions. The invasion of this species is worrying because it is generally a secondary host for viruses harmful to crops [152].

Platycladus orientalis (L.) Franco

Cupressaceae-Phanerophyta caespitosa-East and South-East Asia-Neophyte Change of status for Lazio: from casual alien to naturalized alien

Notes-This species is recorded as a casual alien for the Lazio region by Galasso et al. [34]. In Guarcino, several individuals were found growing on a limestone cliff and on a roadside, not far from artificial conifer reforestations. Google Street images (https: / www. google.it/maps /@41.8013644,13.3183157,54m/data=!3m1!1e3?hl=it\&authuser=2, accessed on 15 September 2021) show the presence of the species on a cliff already in September 2008, supporting evidence of its naturalization.

\section{Potentilla indica (Andrews) Th.Wolf}

Rosaceae-Hemicryptophyta rosulata-South and South-East Asia-Neophyte First record for Abruzzo (casual alien)

Notes-Potentilla indica is reported often as a naturalized alien for many Italian regions, except for Abruzzo, Molise, Puglia, Basilicata, Calabria and Sicilia [34]. A small population about $10 \mathrm{~m}^{2}$ of this neophyte was observed in anthropogenic environments at Raiano in Abruzzo. These individuals were accidentally introduced by nurseries as weeds on lawns.

Prunus avium (L.) L.

Rosaceae-Phanerophyta scaposa-Europe, South-West Asia and North Africa (?) Change of status for Calabria: from naturalized alien to native

Notes-Prunus avium is a tree mainly distributed in Europe, often also cultivated for its appreciated fruits [29]. It is considered an alien only in some central Italian regions (Umbria and Marche), and in Calabria, Sicilia and Sardegna, while in other regions it is classified as a native plant [33]. Pending further studies on the chorology of this species, in Calabria it should be considered indigenous, consistent with the neighboring southern Italian regions. In this region, it generally grows in anthropogenic environments and, albeit sporadically, in the natural deciduous forests (i.e., Longobardi, Marano Marchesato, Motta San Giovanni, Nardodipace, and San Roberto).

\section{Prunus laurocerasus L.}

Rosaceae-Phanerophyta scaposa/caespitosa-South-West Asia-Neophyte First record for Basilicata (casual alien)

Notes-Prunus laurocerasus, a species very frequently cultivated in the Italian gardens [29], is recorded as a casual, naturalized or invasive alien in many Italian regions, except for Molise, Basilicata, Sicilia and Sardegna [34,70,71]. In Basilicata (Potenza), we recently observed a single individual originating by seed in the herb layer of a peri-urban oak woodland.

\section{Rosa andegavensis Bastard}

Rosaceae-Nano-Phanerophyta-Europe and North-West Africa First record for Calabria (native)

Notes-According to the literature [33], the current Italian distribution of Rosa andegavensis includes all regions, except Veneto (only ancient data), Calabria and Sicilia. However, two small populations of this shrub were also found in Verbicaro in northern Calabria. 


\section{Rudbeckia hirta L.}

Asteraceae-Hemicryptophyta biennia-North America-Neophyte

First record for Lazio (casual alien)

Notes-Rudbeckia hirta is recorded as a casual or naturalized alien for all the regions of continental Italy, except for Valle d'Aosta where it is considered doubtful [34,73]. Some individuals were recently found in an anthropogenic environment at Fumone in Lazio, probably spread by the seeds of plants cultivated nearby. Therefore, our record is the first for Lazio and peninsular Italy.

Rumex patientia L. subsp. patientia

Polygonaceae-Hemicryptophyta scaposa-Asia (?)—Archaeophyte

Confirmation for Umbria (casual alien)

Notes-Rumex patientia subsp. patientia, probably native to Asia, is reported as a naturalized or casual alien for many Italian regions [34]. Since in Umbria it was indicated as doubtful [34], our recent find at Foligno of two small populations confirms the presence as a casual alien of this neophyte for the regional flora.

\section{Sedum palmeri S.Watson}

Crassulaceae-Chamaephyta succulenta-Central America-Neophyte

Change of status for Toscana: from casual alien to naturalized alien

Notes-This species is often cultivated as an ornamental plant (A. Stinca, pers. comm.), and is recorded as casual or naturalized in several Italian regions [34,69-72]. In the historic center of Siena, it is established at several sites especially on roofs and gutters, and sometimes on walls. We propose to change its status from casual to naturalized alien in Toscana.

\section{Sedum spathulifolium Hook. var. spathulifolium}

Crassulaceae-Chamaephyta succulenta-North America-Neophyte

First record for Europe (casual alien)

First record for Marche (casual alien)

First record for Umbria (casual alien)

Notes-Sedum spathulifolium var. spathulifolium is a perennial herb native to North America, rarely cultivated in Italy (A. Stinca, pers. comm.). Three small populations of this neophyte were observed in anthropogenic environments in central Italy, two in the Marche region (i.e., Cagli and Falconara Marittima; Figure 2F) and one in the Umbria region (i.e., Scheggia e Pascelupo). These individuals appear to have spread from the seeds of plants cultivated nearby. However, it cannot be excluded that their propagation may be due to the involuntary dispersion of vegetative parts, perhaps by animals. As far as we know, these are the first find of this species in Europe. For the nomenclature and identification of the samples collected, we followed Ohba [153].

Senecio angulatus L.f.

Asteraceae-Chamaephyta fruticosa-South Africa-Neophyte

Change of the status for Calabria: from casual alien to naturalized alien

Notes-Species considered as casual for Calabria by Galasso et al. [34]. However, in Reggio Calabria, we monitored a large population that occupies the entire valley floor for several hundred meters. In this site, Senecio angulatus has long been self-maintaining and flowers abundantly every year. For these reasons, the species can be considered naturalized for Calabria, like in other southern Italian regions and Sicily.

Setaria italica (L.) P.Beauv. subsp. italica

Poaceae-Therophyta scaposa-China-Archaeophyte

Change of status for Calabria: from doubtful record to casual alien

Notes-An annual herb native to China, Setaria italica subsp. italica is currently present as a casual alien in almost all Italy, while it is doubtful for Valle d'Aosta and Calabria [34]. However, a small population composed by few individuals spread by the seed was recently discovered by us also in the southern part of Calabria in the Reggio Calabria municipality. 
Setaria italica (L.) P.Beauv. subsp. pycnocoma (Steud.) de Wet

Poaceae-Therophyta scaposa-Asia (?)-Neophyte

Change of status for Marche: from casual alien to naturalized alien

Notes-Setaria italica subsp. pycnocoma is currently present in all regions of northern and central Italy (excluding Umbria and Lazio) and in Sardinia [34]. Its spread to the Marche region (i.e., Acqualagna, Ancona, Cagli, Cartoceto, Fano, Magliano di Tenna, and Serra San Quirico) and the increasing capacity to colonize grassland communities with even very different ecological characteristics to the detriment of other grassland species shows a behavior typical of invasive species.

\section{Solanum tuberosum L.}

Solanaceae-Geophyta rhizomatosa-South America-Neophyte Confirmation for Sicilia (casual alien)

Notes-Solanum tuberosum, a South American plant known as a casual alien in almost all Italian regions [34,72], was reported generically for Sicilia by Giardina et al. [154] as "commonly cultivated and subspontaneous near fields". However, this report was overlooked in the Italian alien checklist [34]. Therefore, we confirm its presence as a casual species escaped from cultivation in Sicilia (Catania).

\section{Solidago gigantea Aiton}

Asteraceae-Hemicryptophyta scaposa-North America-Neophyte

Change of status for Lazio: from casual alien to naturalized alien

Notes-Solidago gigantea is a hemicryptophyte introduced from North America. It is reported for several Italian regions, but only in the North is it described as an invasive species [34]. In Lazio, this neophyte was observed, in recent years, in expansion along the Fiume Aniene (Marano Equo) in the absence of cultivated plants nearby. Therefore, we propose to change its status from casual to naturalized in Lazio.

\section{Stenotaphrum secundatum (Walter) Kuntze}

Poaceae-Hemicryptophyta reptantia/Geophyta rhizomatosa-Tropical America and Africa-Neophyte

First record for Basilicata (casual alien)

Notes-Stenotaphrum secundatum is often cultivated for lawn grasses in thermotemperate Italian coastal areas due to its aesthetic characteristics and its marked rusticity (A. Stinca, pers. comm.). It is recorded as a casual alien species in various Italian regions [34]. In Basilicata, some spontaneous individuals were observed in the road pavement cracks and at the edge of sidewalks near the beach of Maratea.

Talinum paniculatum (Jacq.) Gaertn.

Talinaceae-Chamaephyta suffrutescentia-North, Central and South America-Neophyte First record for Campania (casual alien)

Notes-Talinum paniculatum, native to Tropical America, is recorded as casual in Italy for Lazio, Sicilia and Sardegna [34,96]. The few individuals observed in Campania (Castellammare di Stabia) spread by seed from cultivated plants nearby. The species should be considered a casual alien in Campania because it does not form stable populations.

Trachelium caeruleum L. subsp. caeruleum

Campanulaceae-Chamaephyta suffrutescentia-West Mediterranean-Neophyte Change of status for Calabria: from naturalized alien to invasive alien

Notes-In the past, it was sometimes cultivated as an ornamental plant in Italy [30]; today, Trachelium caeruleum subsp. caeruleum is naturalized in many regions, especially on the Tyrrhenian side of the Italian Peninsula [34]. In some monitored sites in Calabria (i.e., Bagnara Calabra, Canolo Nuova, Grotteria, Platì, and Sant'Eufemia d'Aspromonte), this taxon spreads for several kilometers: for example, along the Torrente Pachina the species occupies the whole valley, as well as in the locality of Sant'Eufemia d'Aspromonte. Here, 
it tends to invade the rocky environments of the humid gorges and competes with many native species such as Adiantum capillus-veneris L., Geranium versicolor L., Mycelis muralis (L.) Dumort. subsp. muralis, Osmunda regalis L., Polystichum setiferum (Forssk.) T.Moore ex Woyn. and Woodwardia radicans (L.) Sm. Therefore, the species should be considered invasive for Calabria.

Trachelospermum jasminoides (Lind1.) Lem.

Apocynaceae-Phanerophyta lianosa-South-West Asia-Neophyte

First record for Sardegna (casual alien)

Notes-Trachelospermum jasminoides is an Asian liana and a very popular ornamental plant in Italy (A. Stinca, pers. comm.). It is recorded as a casual alien only for Lombardia [34]. Recently, a few individuals were observed in rocky crevices along an escarpment in Cagliari, probably originating from vegetative parts from nearby urban gardens. Therefore, our find is the first for insular Italy.

Trachycarpus fortunei (Hook.) H.Wendl.

Arecaceae-Phanerophyta scaposa-South-East Asia-Neophyte

Change of status for Toscana: from casual alien to naturalized alien

Notes-This ornamental palm is considered an invasive species in some regions of northern Italy, and a casual alien in Toscana and Marche [34,67,69]. At two sites around the historical center of Siena, it was observed abundantly reproducing from seed in urban shrublands and ruderal site, with individuals even reaching medium sizes. We propose to change its status from casual to naturalized in Toscana.

Tradescantia fluminensis Vell.

Commelinaceae-Hemicryptophyta reptantia/Geophyta rhizomatosa-South AmericaNeophyte

Change of status for Calabria: from casual alien to naturalized alien

Notes-The species was reported as casual for Calabria by Galasso et al. [34]. However, in the stations reported here (i.e., Reggio Calabria and San Roberto) some individuals were found to have vegetated for several years and to have produced some new individuals. Hence, Tradescantia fluminensis can be considered naturalized for Calabria. In southern Italy, this neophyte propagates mainly vegetatively, producing a large amount of biomass and, in this way, strongly competes with indigenous species [155].

\section{Tradescantia sillamontana Matuda}

Commelinaceae-Hemicryptophyta reptantia/Geophyta rhizomatosa—North AmericaNeophyte

First record for Sardegna (casual alien)

Notes-Like the previous species, Tradescantia sillamontana is a hemicryptophyte or geophyte often cultivated as an ornamental plant in Italy (A. Stinca, pers. comm.). Based on a discovery in Campania by Stinca et al. [156], it was recorded as a casual alien for the first time in Europe. It was later reported for Calabria by Laface et al. [101] Therefore, according to current knowledge, this species is known only for these two regions [34,72]. However, some individuals were recently found in an anthropogenic environment at Cagliari in Sardegna, probably spread by the seeds of cultivated plants nearby. Therefore, our record is the first for insular Italy.

\section{Tropaeolum majus L.}

Tropaeolaceae-Therophyta reptantia-South America-Neophyte Change of status for Calabria: from naturalized alien to invasive alien

Notes-Tropaeolum majus is a South American therophyte often cultivated as ornamental in Italy. It is reported as a naturalized alien in Calabria [34]. However, several individuals were found in the new sites (i.e., Bova Marina, Condofuri, Motta San Giovanni, and Reggio Calabria), showing a high capacity to spread rapidly and occupy ever larger surface areas. Therefore, the species should be considered invasive for Calabria. 


\section{Ulmus pumila $\mathrm{L}$.}

Ulmaceae-Phanerophyta scaposa-Asia-Neophyte

Change of status for Lazio: from casual alien to naturalized alien

Notes-Ulmus pumila, often cultivated as an ornamental plant in Italy [29], was reported as casual, naturalized or invasive in several Italian regions [34,71,73]. In Lazio, based on some populations detected in Roma and Sabaudia $[90,96]$, it is considered a casual species [34]. In Alatri, we found a new population with numerous individuals originating from seed from ornamental trees that were planted in the mid-1990s. They appear wellestablished and sexually reproducing in a range up to $200 \mathrm{~m}$ away from mother plants, with some individuals up to $5 \mathrm{~m}$ tall. We thus propose a status change for the species in Lazio, from casual to naturalized alien.

Verbascum thapsus L. subsp. montanum (Schrad.) Bonnier \& Layens

Scrophulariaceae-Hemicryptophyta biennia—South-East European Orophyte Confirmation for Puglia (native)

Notes-The known Italian distribution of Verbascum thapsus subsp. montanum includes all continental regions, Toscana and Campania [33]. However, Curti et al. ([157] sub Verbascum crassifolium) reported this taxon also for Lesina in northern Puglia. Later, Forte et al. ([158] sub Verbascum thapsus subsp. crassifolium) mention it for the same locality but only according to the information provided by Curti et al. [157]. Fortunately, a specimen collected at Lesina on May 1978 and preserved in MJG-Herb. Garganicum allow us to confirm Verbascum thapsus subsp. montanum for the flora of Puglia.

\section{Veronica agrestis $\mathbf{L}$.}

Plantaginaceae-Therophyta scaposa-European

Confirmation for Puglia (native)

Notes-Veronica agrestis is a native weed, often present in Italy in the cultivated fields [124]. According to Bartolucci et al. [33] Veronica agrestis does not occur in Puglia. However, Curti et al. [157] reported this taxon for Lesina in northern part of the region. Later, Forte et al. [158] do not mention it for Lesina. Fortunately, a specimen from Vico del Gargano preserved in MJG-Herb. Garganicum allows Veronica agrestis to be confirmed for the flora of Puglia.

\section{Veronica cymbalaria Bodard subsp. cymbalaria}

Plantaginaceae-Therophyta scaposa-Euri-Mediterranean

First record for Puglia (native)

Notes-Veronica cymbalaria subsp. cymbalaria is reported as a native taxon from Lombardia, Liguria, Emilia-Romagna and from peninsular and insular Italy, except Puglia and Basilicata [33]. Here, we provide the first records of this taxon for Puglia, all from the Gargano promontory (see also [123]).

\section{Veronica persica Poir.}

Plantaginaceae-Therophyta scaposa-South-West Asia-Neophyte

Change of status for Calabria: from naturalized alien to invasive alien

Notes-Veronica persica is an Asian annual weed easily propagated by seed. It is considered an invasive or naturalized alien in all Italian regions, and in particular, as naturalized in Calabria [34]. Recent field observations revealed that this exotic species grows abundantly in anthropogenic places including cultivated fields, especially in coastal areas. The seeds are likely to be transported by agricultural vehicles or by moving horticultural plants. Therefore, this species should be considered invasive for the region.

Vitis $\times$ koberi Ardenghi, Galasso, Banfi \& Lastrucci

Vitaceae-Phanerophyta lianosa-Artificial origin-Neophyte

First record for Umbria (invasive alien)

Notes-Vitis $\times$ koberi, an artificial hybrid of American grapevines, i.e., Vitis berlandieri Planch. and Vitis riparia Michx. [159], is recorded as an invasive or naturalized alien in 
almost all Italian regions, except Umbria and Basilicata $[34,69,160]$. Recently, we discovered some large populations also at Foligno in Umbria, where it showed a noticeable vegetative propagation in anthropogenic environments. In addition to the above cited localities, we observed this taxon as being abundant along the SS 75 road from Foligno to Perugia and along the motorway junction up to the A1 motorway. Therefore, we propose this species as an invasive alien in Umbria.

\section{Vitis labrusca L.}

Vitaceae-Phanerophyta lianosa-North America—Neophyte

First record for Marche (casual alien)

Notes-Vitis labrusca is a climbing shrub native to the eastern USA and belonging to the grouping of "American vines". Introduced as a table grape in Europe before the advent of phylloxera, its cultivation was later supplanted by species or varieties more resistant to this pathogen. Currently, the species is present in almost all Italian regions except for Valle d'Aosta, Trentino-Alto Adige, Marche, Umbria and Molise [34,69]. However, a new population was discovered in Marche near the banks of the Fiume Metauro (Peglio).

\section{Vitis rupestris Scheele}

Vitaceae-Phanerophyta lianosa-North America-Neophyte

First record for Umbria (casual alien)

Notes-Vitis rupestris is reported as a casual alien in several Italian regions [34]. Recently, a single individual was observed in the urban area of Spello in Umbria.

Zephyranthes candida (Lind1.) Herb.

Amaryllidaceae-Geophyta bulbosa-South America-Neophyte First record for Calabria (casual alien)

Notes-Zephyranthes candida is a geophyte native to Central-East part of South America, sometimes cultivated as an ornamental plant in Italy (A. Stinca, pers. comm.). It is reported as a casual alien only for Toscana [34]. A small population was also observed also in Reggio Calabria, probably derived from vegetative parts present in the soil brought back. Therefore, our discovery extends its distribution range into southern Italy.

\subsection{Current Floristic Knowledge in Italy}

Currently, without counting the taxa reported by mistake, that are doubtful, data deficient, extinct or no longer recorded after 1950, the Italian vascular flora comprises 9150 taxa of which 7547 are native (of which 1598 are Italian endemics; i.e., $21.17 \%$ of total native taxa) and 1603 are exotic at a national level. Therefore, related to the total current plant diversity, the contribution of exotic taxa is $17.52 \%$. As for the alien flora, casual species number $761(47.47 \%$ of total alien taxa), naturalized are $601(37.49 \%)$, invasive taxa number $238(14.85 \%)$, while the not assessed ones (i.e., without indication of the invasiveness status) are only three $(0.19 \%)$. The Italian floristic density (i.e., number of taxa/area) is $0.025 \mathrm{taxa} / \mathrm{km}^{2}$ for native units and $0.005 \mathrm{taxa} / \mathrm{km}^{2}$ for alien ones.

At the regional scale (Table 2), the greatest richness of native species (including cryptogenics) is found in Toscana ( $\mathrm{R} n=3202$ taxa) followed by Piemonte (3028), Lombardia (2926) and Abruzzo (2920). Instead, the region with the greatest presence of the alien taxa (including alien at regional level) is Trentino-Alto Adige (Rt $a=959)$ followed by Lombardia (955), Veneto (785) and Friuli-Venezia Giulia (641). With 118 taxa, Lombardia is the Italian region with the highest number of invasive alien plants. Friuli-Venezia Giulia results the region with the largest number of aliens without indication of the invasiveness status (77), while in Campania and Puglia this category of exotic plants is absent. 


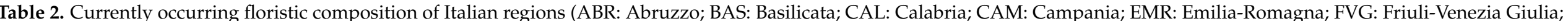

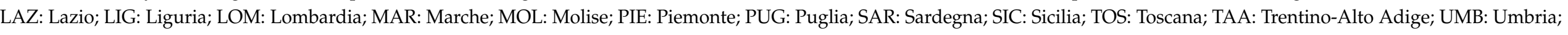

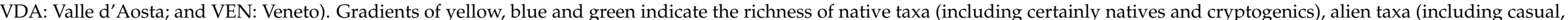

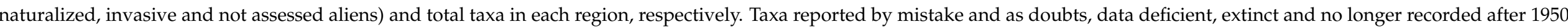
are not counted.

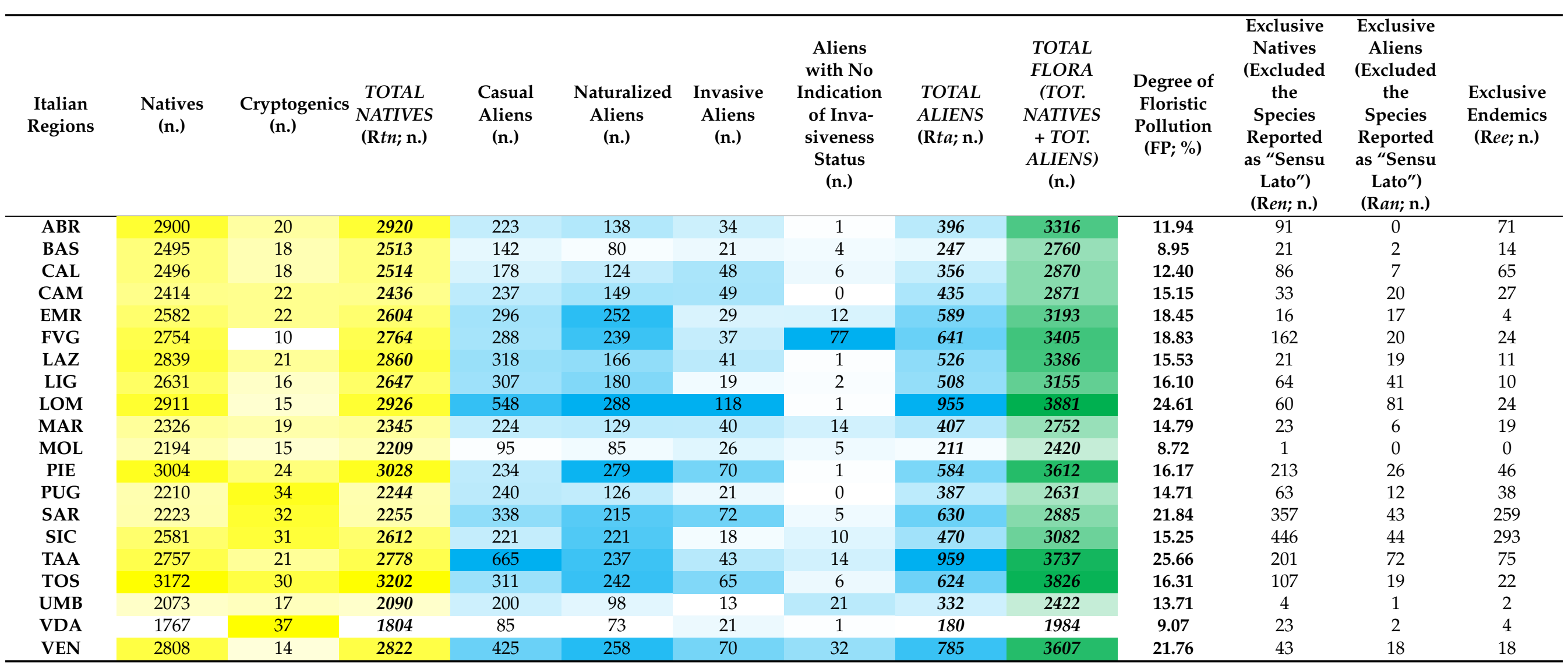


Analyzing the degree of floristic pollution (FP) of each regional flora, we found that only in Molise, Basilicata and Valle d'Aosta do alien species currently present in these areas not exceed $10 \%$ of the total flora. At the other extreme, the regions in which alien taxa are about $25 \%$ of the total flora are Trentino-Alto Adige and Lombardia (Table 2).

The regions of insular Italy are clearly those with the highest number of exclusive native taxa (i.e., Italian endemics + taxa with wider distribution but reported in only one Italian region): Sicilia (Ren $=446$; i.e., $17.08 \%$ of total regional native taxa) and Sardinia (357; $15.83 \%$ ). Conversely, Lombardia (Rea $=81$; i.e., $8.48 \%$ of total regional alien taxa) and Trentino-Alto Adige $(79 ; 7.51 \%)$ are the regions with the highest number of exclusive alien taxa (Table 2, Figure $3 \mathrm{~A}, \mathrm{~A}^{\prime}$ ). It is interesting to note that Sicilia also results as the region with the highest percentage of exclusive alien taxa on the total of its exotic flora $(9.36 \%)$ (Figure 3). As for the exclusive endemic taxa of a single Italian region (i.e., regional endemics; the complete list are available in Table S2), the islands of Sicilia (Ree = 293; i.e., $11.22 \%$ of total regional native taxa) and Sardegna $(259 ; 11.49 \%)$ results the richest territories of Italy (Table 2, Table S3).

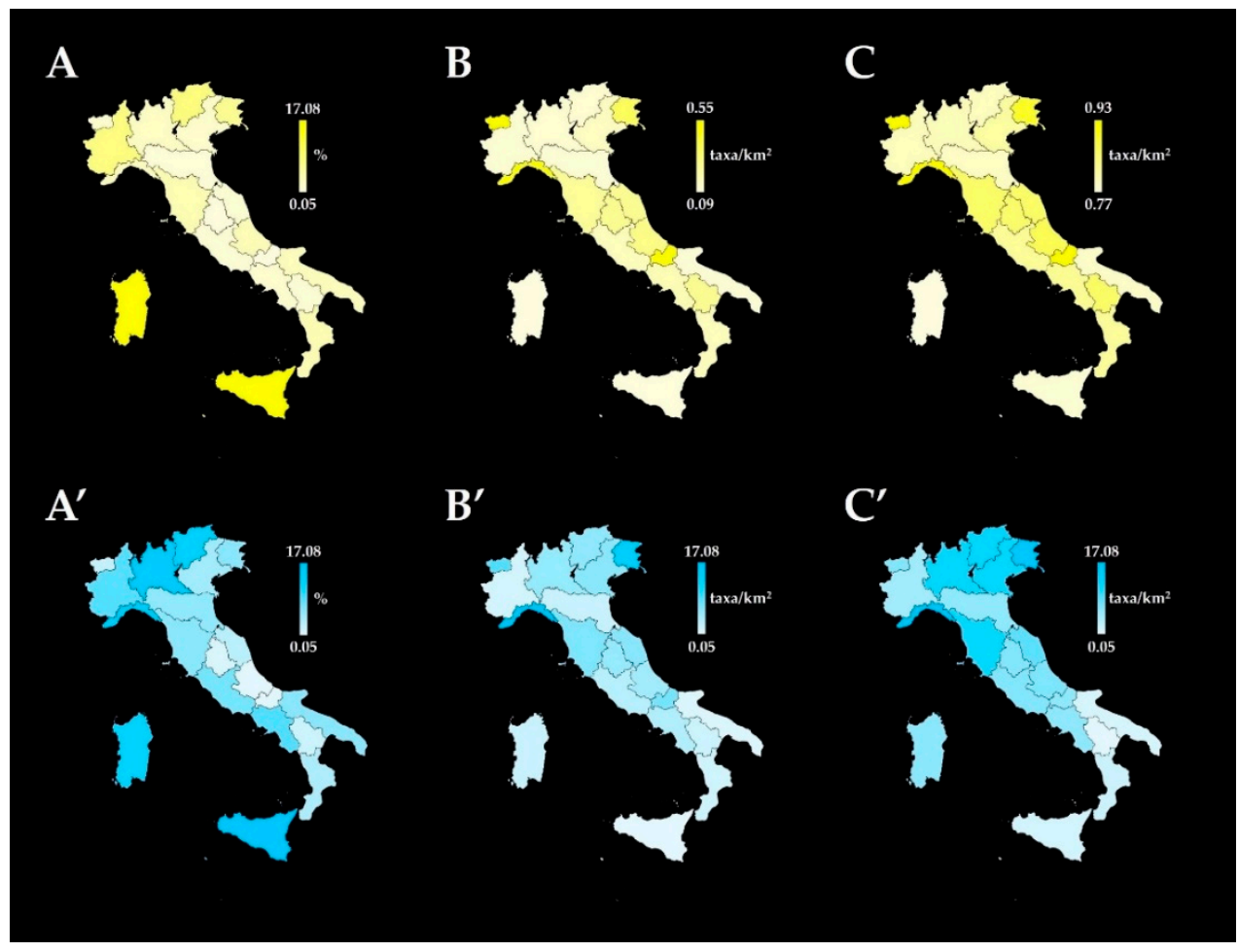

Figure 3. Current percentage of exclusive native (Ren) (A) and alien (Rea) ( $\left.\mathbf{A}^{\prime}\right)$ taxa of the Italian regions. Density of total native (Dtn) $(\mathbf{B})$ and alien (Dta) $\left(\mathbf{B}^{\prime}\right)$, and normalized density of total native $(\mathrm{DN} t n)(\mathbf{C})$ and total alien (DNta) $\left(\mathbf{C}^{\prime}\right)$. Values of Ren, Rea, Dtn, Dta, DNtn and DNta for each region are available in Table S3. Taxa reported by mistake and as doubts, data deficient, extinct and no longer recorded after 1950 are not counted.

Considering the floristic density at the regional level, Valle d'Aosta (Dtn $=0.553 \mathrm{taxa} / \mathrm{km}^{2}$; $\left.\mathrm{DN} t n=0.927 \mathrm{taxa} / \mathrm{km}^{2}\right)$, Molise $(0.495 ; 0.916)$ and Liguria $(0.489 ; 0.917)$ showed the highest values for native taxa (Figure 3B,C). Likewise, Liguria (Dta $=0.094$; DN $t n=0.725$ ) and FriuliVenezia Giulia $(0.081 ; 0.720)$ are the areas with the highest density of alien taxa (Figure $\left.3 \mathrm{~B}^{\prime}, \mathrm{C}^{\prime}\right)$.

As presented in Figure 4, the regional floristic index applied only to native taxa (RFIn), which ranges from 1.242 in Toscana to 0.700 in Valle d'Aosta, shows values above 1 (i.e., average value) in the regions of continental Italy (except Valle d'Aosta), Toscana, Abruzzo, Lazio and Sicilia. Considering only the alien taxa, RFI $a$ shows a greater gap between the maximum value (1.876 in Trentino-Alto Adige) and the minimum (0.352 in Valle d'Aosta). RFI $a$ values are also higher for the northern Italian regions (except Liguria), Sardegna, 
Toscana and Lazio. RFI calculated to total regional taxa (RFIt) confirms the trend shown by $\mathrm{RTI} n$ and is between 1.256 in Lombardia and 0.642 in Valle d'Aosta.

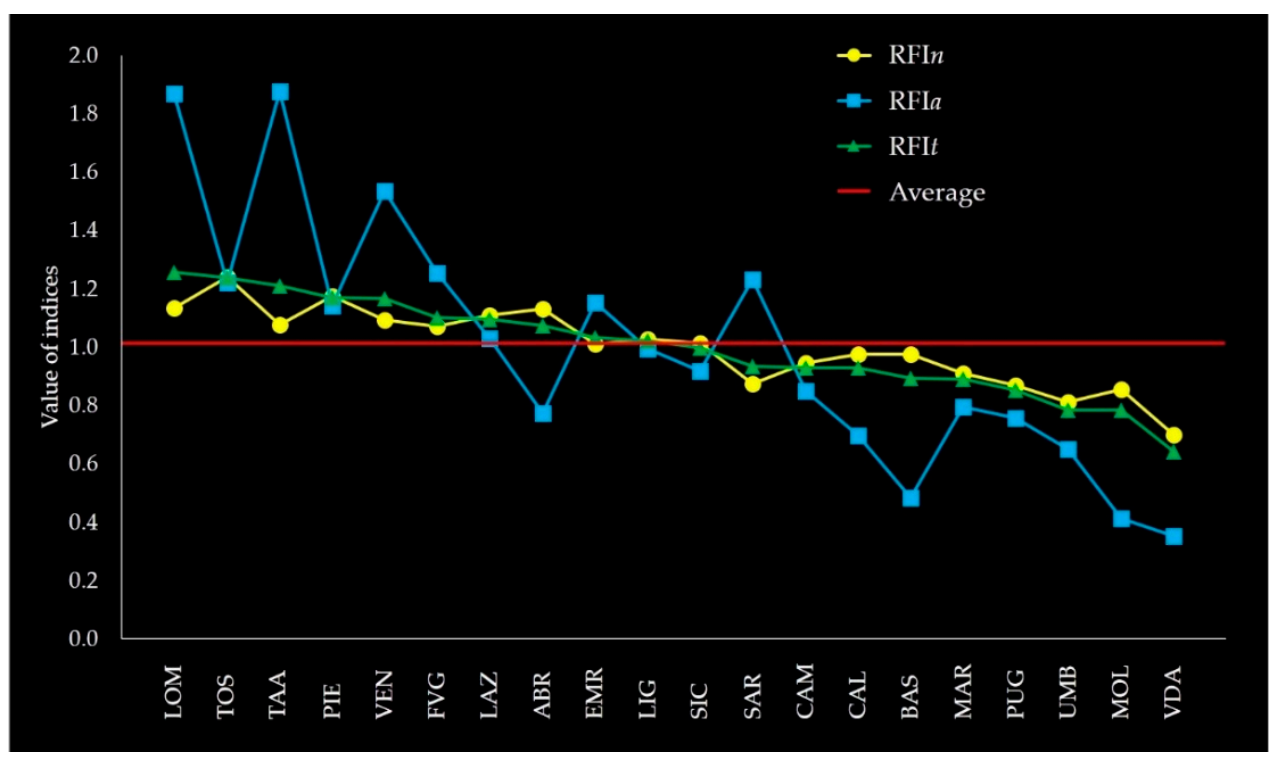

Figure 4. Trend of the regional floristic index applied only to only native taxa (RFIn, yellow curve), only alien taxa (RFI $a$, blue curve) and the total taxa (RFI $t$, green curve) currently present in each Italian region (ordered according to RFI $t$ values: LOM: Lombardia; TOS: Toscana; TAA: Trentino-Alto Adige; PIE: Piemonte; VEN: Veneto; FVG: Friuli-Venezia Giulia; LAZ: Lazio; ABR: Abruzzo; EMR: Emilia-Romagna; LIG: Liguria; SIC: Sicilia; SAR: Sardegna; CAM: Campania; CAL: Calabria; BAS: Basilicata; MAR: Marche; PUG: Puglia; UMB: Umbria; MOL: Molise; and VDA: Valle d'Aosta). The red line represents the average number of only native, only alien and total taxa present in all regions (i.e., RFI = 1). Values of RFI $n$, RFI $a$ and RFI $t$ for each region are available in Table S4. Taxa reported by mistake and as doubts, data deficient, extinct and no longer recorded after 1950 are not counted.

The classification and ordination analysis of the flora of the Italian admistrative regions considering data matrices of only native taxa at the regional level (data matrix of 7697 taxa $\times 20$ regions; taxa include species reported as "sensu lato"), only alien taxa at the regional level (2337 taxa $\times 20$ regions) and the total taxa (9330 taxa $\times 20$ regions) are depicted in Figure 5. The dendrogram resulting from the agglomerative hierarchical clustering of only native taxa currently present in the Italian regions show three clearly distinct groups (i.e., I, II and III; Figure 5A). Three main groups are characterized by exclusive native taxa (i.e., exclusively common to all regions of the group) which are respectively 159, 68 and 22 (Figure 5A', Table S5). Cluster I includes all Alpine regions divided into two subgroups according to a longitudinal gradient, i.e., Piemonte and Valle d'Aosta in subgroup I $a$, and Friuli-Venezia Giulia, Veneto, Lombardia and Trentino-Alto Adige in subgroup I $b$. Within group II, there are all southern regions of the Italian Peninsula (subgroup II a: Puglia, Calabria, Basilicata and Campania) and the regions of insular Italy (subgroup IIb: Sardegna and Sicilia). The regions of central Italy (Marche, Umbria, Molise, Abruzzo and Lazio) are instead grouped in subgroup III $a$, with the exception of Toscana which clasterizes in subgroup III $b$ together with Liguria and Emilia-Romagna. The cluster analysis performed on the matrix of only alien taxa show two distinct groups, although with a much lower value of dissimilarity than the main groups of only native taxa (ca. 500 vs. 1500) (Figure 5B). Indeed, two main groups are distinguished by only four exclusive alien taxa (Figure 5B', Table S5). Within group I there are all the regions of peninsular and insular Italy, as well as Valle d'Aosta and Liguria. The remaining continental regions are instead grouped in cluster II. As for the dendrogram obtained by total taxa, it shows two clearly distinct groups (Figure 5C). Group I's results are identical to those of only native taxa, while cluster II includes four subgroups which are II $a$ (with Sardegna and Sicilia), II $b$ (Liguria, 
Emilia-Romagna and Toscana), IIc (Marche, Umbria, Abruzzo and Lazio), and IId (Puglia, Basilicata, Calabria, Campania and Molise).
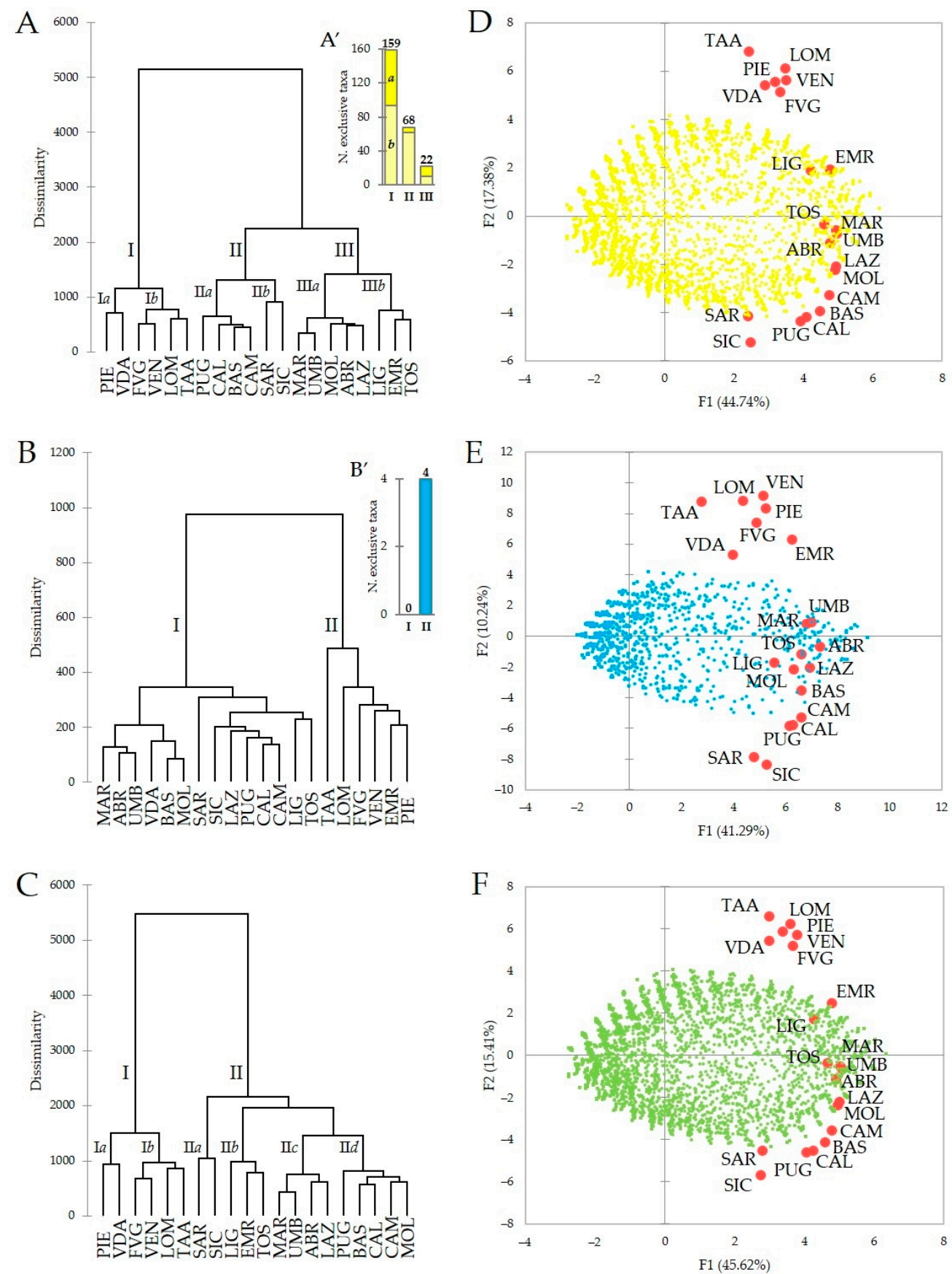

Figure 5. Dendrogram of the agglomerative hierarchical clustering (A-C, with an indication of the main groups and subgroups) and biplot of the principal component analysis in the first two principal components space (D-F) of current flora of the Italian administrative regions considering only native taxa $(\mathbf{A}, \mathbf{D})$, only alien taxa $(\mathbf{B}, \mathbf{E})$ and the total taxa $(\mathbf{C}, \mathbf{F})$. Histograms show the number of exclusive native $\left(\mathbf{A}^{\prime}\right)$ and alien $\left(\mathbf{B}^{\prime}\right)$ taxa of the main clusters (the complete list are available in Table S5). Taxa reported by mistake and as doubts, extinct and no longer recorded after 1950 are not counted (ABR: Abruzzo; BAS: Basilicata; CAL: Calabria; CAM: Campania; EMR: Emilia-Romagna; FVG: Friuli-Venezia Giulia; LAZ: Lazio; LIG: Liguria; LOM: Lombardia; MAR: Marche; MOL: Molise; PIE: Piemonte; PUG: Puglia; SAR: Sardegna; SIC: Sicilia; TOS: Toscana; TAA: Trentino-Alto Adige; UMB: Umbria; VDA: Valle d'Aosta; and VEN: Veneto). 
In all biplots (Figure 5D-F), the clusters of regions are highlighted along the first axis (F1) which accounted for $44.74 \%, 41.29 \%$ and $45.62 \%$ of the variation considering native, alien and total flora, respectively (to improve readability species variables are not shown). However, the 20 regions showed a separation according to the second axis (F2), which accounted for $17.38 \%$ (native flora), $10.24 \%$ (alien flora) and $15.41 \%$ (total flora) of the remaining variation and clearly reflected their geographical location. With some exceptions concerning only the alien taxa (i.e., the position of Valle d'Aosta, Sicilia and Sardegna), the results shown by the biplots are consistent with those of the dendrograms.

\section{Discussion}

\subsection{New Findings and Updates}

Our research concerned 125 taxa and allowed us to propose 134 floristic updates for Italy (Table 1), in addition to discoveries of new growth sites for four Italian rare species. Most of the taxa recorded (i.e., not considering Kalanchoë daigremontiana, since it was excluded from the flora of Calabria) belong to the Asteraceae (13.71\%), are phanerophytes $(29.03 \%)$, native to the Americas (37.90\%) and neophytes $75.81 \%)$. Four taxa, all exotic, are reported for the first time in Italy. Elaeodendron croceum (native to South Africa), Kalanchoë blossfeldiana (Madagascar) and Sedum spathulifolium var. spathulifolium (North America) were recorded as casual aliens, while the historic presence of Oxalis brasiliensis (South America) was only certified by specimens stored in herbarium FI. On the basis of the available floristic literature all these taxa are to be considered new for the European flora. Likewise, Kalanchoë laxiflora from Madagascar can be considered as a confirmed alien species for Italy and Europe as a whole.

In all, our floristic updates covered 14 of the 20 Italian regions (Table 1). The region for which we proposed the largest number of updates was Calabria (44, of which 5 were first records), followed by Umbria and Toscana. Fifty-nine taxa were reported as new in one or more Italian regions. The largest number of first reports were recorded in Umbria (10 taxa, all exotic) and Marche (10 taxa, of which nine are alien). These data are not surprising since, with the exception of the information reported in the national checklist [34] and in its updates [67-73], detailed studies on alien flora have not recently been performed in these two regions. On the contrary, the high number of first reports from Campania (9 taxa, all alien), a region in which many studies on alien plants have been conducted in recent years $[25,42,129,149,156,161]$, is mainly due to recent introductions. With the exception of the fern Nephrolepis cordifolia all the other floristic notes concern angiosperms and gymnosperms. These data were predictable, since new reports concerning ferns have been very rare in recent years in all European countries [162]. As for the discoveries of Chimonanthus praecox in Marche, Coleus scutellarioides in Calabria, Echinochloa hispidula in Toscana, and Rudbeckia hirta in Lazio, we point out that these are the first findings as casual alien plants in peninsular Italy. Likewise, Tradescantia sillamontana and Trachelospermum jasminoides found as casual in Sardegna were also recorded as new for insular Italy. Furthermore, the discovery in Campania of a naturalized population of Cenchrus setaceus was of particular interest because this neophyte is included in the list of invasive alien species of the European Union (Commission Implementing Regulation (EU) 2017/1263, https: / / eur-lex.europa. eu/legal-content/EN/TXT/?WT.mc_id=Twitter\&uri=CELEX:32017R1263, accessed on 7 September 2021). It has ecophysiological traits that make her an aggressive invader in the arid and semi-arid environments of the tropics and subtropics [163], but also in the natural (e.g., perennial dry grasslands with Hyparrhenia hirta (L.) Stapf.) and anthropogenic environments (e.g., along the roads) of Calabria, Sicilia and Sardegna [101,164]. We believe that our reports can be useful to local authorities to plan the appropriate eradication actions in order to prevent ecological damage. We emphasize that the discovery sites are located not far from protected natural areas such as the Vesuvio National Park and the Regional Parks of Fiume Sarno, Monti Lattari, Partenio and Monti Picentini.

On a regional scale, based on plant population monitoring over time and on analysis of the literature, we assigned to some of the examined taxa a different invasiveness status 
or a different indigenous status compared with the past assessment. The analysis also made it possible to update the invasiveness status at national level for 10 species as follows: from casual to naturalized (Campanula portenschlagiana, Morus nigra, Phyllostachys edulis), and from naturalized to invasive (Arctotheca calendula, Crassula muscosa, Dactyloctenium aegyptium, Digitaria ciliaris, Kalanchoë $\times$ houghtonii, Trachelium caeruleum subsp. caeruleum, Tropaeolum majus). Interestingly, most changes of the invasiveness status and indigenous status result from observations carried out in Calabria (Table 1). This data is undoubtedly due to the lack of knowledge on alien flora in this region. Indeed, only recently some studies focused their attention on exotic species at the regional level and in part have filled this knowledge gap [101,122,129,150]. For some invasive species we have also observed significant negative impacts on habitats of interest to the European Community (Habitat Directive 92/43/EEC, https:/ / eur-lex.europa.eu/legal-content/EN/TXT/?uri=celex\% 3A31992L0043, accessed on 7 September 2021): Acanthus mollis subsp. mollis (on habitat 9340), Arctotheca calendula (2110 and 2120), Crepis sancta subsp. nemausensis (6110*) and Dactyloctenium aegyptium (2110, 2120 and 2230). With the exception of $A$. calendula, for all other exotic taxa these are the first evidence of impacts on EU habitat in Italy [165].

Most of the 59 taxa reported for the first time for the Italian regions are escapees from cultivation (e.g., Actinidia deliciosa, Boerhavia coccinea, Campanula portenschlagiana and Elaeagnus $\times$ submacrophylla). This is fully in agreement with other authors according to whom agricultural activities and artificial green areas (gardens, parks and cultivated fields) represent starting points for the process of invasion [93,166,167]. In addition to human activities, the large number of alien species reported as new for Italy and for its regions should be related to the recent greater attention of Italian botanists to this group of plants. In any event, our results are in line with the trend of increasing reports of alien species in Italy [46] and Europe [167].

The few new reports of indigenous plants at the regional level mostly concern taxa with wide ranges such as Deschampsia cespitosa subsp. parviflora (Eurasian, discovered in Abruzzo), Rosa andegavensis (Europe and North-West Africa, found in Calabria) and Verbascum thapsus subsp. montanum (South-East European Orophyte, recorded in Puglia). We point out that Deschampsia cespitosa subsp. parviflora is a taxon difficult to identify and probably underestimated in Italy. For this reason, it was categorized as DD (i.e., data deficient) in the IUCN Red List of the Italian Flora [168,169]. Of great interest was the discovery of new populations of two rare native species: Astragalus penduliflorus (in Lazio) and Cerinthe retorta (in Puglia). As for the latter species, it previously received the conservation status EN (i.e., endangered) in the IUCN Red List of the Italian Flora [168-170] and new site discovered by us in the Gravina di Laterza does not lead to a change of the IUCN category. Additionally, noteworthy was the discovery of a new population for the Monti Aurunci (Lazio) of the Italian endemic Drymochloa drymeja subsp. exaltata, a taxon listed in the IUCN Red List of the Italian Flora as LC (i.e., least concern) [47,168], common in southern Italian Peninsula but very rare in central Italy. Useful to clarify the current distribution in Italy were also the discoveries of new growth sites for Andrachne telephioides in Lazio and Campania. The occurrence of this species in Italian regions has been variously interpreted by the researchers [33] and, in our opinion, further investigations on its chorology are necessary in the Mediterranean basin.

The revision of the specimens preserved in FI, HLUC, PORUN-Herb. Stinca, PI, Herb. Magellense, MJG-Herb. Garganicum and SIENA led to a review or confirmation of some previous reports. In detail: (i) three samples were found in FI which testify to the presence of Oxalis brasiliensis in Italy in the 1930s; in HLUC, we traced and confirmed a single unpublished specimen of Centaurium erythraea subsp. rhodense from Basilicata; (ii) a revision of some exsiccata preserved in PORUN-Herb. Stinca and PI previously identified as Parthenocissus quinquefolia led to Parthenocissus inserta added to the flora of Campania and Calabria; (iii) in MJG-Herb. Garganicum, we traced and confirmed one unpublished specimen of Verbascum thapsus subsp. montanum from Puglia; (iv) the reexamination of a specimen of Artemisia campestris subsp. glutinosa conserved in the Herb. 
Magellense led us to correct it to Artemisia campestris subsp. campestris which was therefore confirmed for the flora of Abruzzo; and (v) in SIENA, we traced and confirmed a single unpublished specimen of Echinochloa hispidula from Toscana. These examples confirm the essential role of herbaria in botanical researches [171,172].

As regards the current richness of the native vascular flora and endemics in Italy, in accordance with Bartolucci et al. [33,46], we confirm Italy's primacy compared to other European floras for which we have fairly update-to-date data; that is, France [173], Albania [174], Greece [175], Spain, Portugal [176] and the Czech Republic [177]. We emphasize that the number of native taxa occurring in Italy, like in other countries, is subject to continuous changes resulting from new discoveries, new descriptions and taxonomic revisions. The high richness of the Italian flora can be related by the marked environmental diversification of the territory. Indeed, four "biogeographical provinces", i.e., the Alpine, the Apennino-Balkan, the Italo-Tyrrhenian and the Adriatic, meet in Italy [58]. As regards the alien flora, although it does not have updated data for most of the European countries [178-182], Italy ranks among the first countries also for the number of exotic taxa currently reported.

\subsection{Exploration of Floristic Similarities between Regions}

Our study was the first to statistically explore floristic similarities between Italian administrative regions using currently occurring native, alien and total taxa separately, as well as updated to 2021. Indeed, previously only Blasi et al. [183] merely used native floras for multivariate analyses. Other few studies analyzed the Italian floristic composition only in quantitative [46] and chorological terms [184], or using only Italian endemics [185] or only native woody genera [186]. Our multivariate analysis of updated floristic data on a regional scale is interesting from several points of view. As shown in the graphs of the Figure 5A,D regarding only native taxa, the regions are clearly distributed along the latitudinal gradient. Interestingly, in the biplot of Figure 5D, the regions are clearly divided into continental, peninsular and insular Italy. Only Liguria and Emilia-Romagna are placed in an intermediate position between the northern and the peninsular regions, but this reflects their natural geographical location and the environmental characteristics. Our data thus fully confirm the hypothesis regarding a different regional floristic composition along the North—South geographic gradient and are in full agreement with Blasi et al. [183]. The detection of six subclusters based on native and total taxa is consistent with the results by Abbate et al. [186], that highlighted how Italian regions cluster in six groups based on native woody genera; however, such groups are only partially consistent with ours in terms of included regions. Furthermore, our results do not confirm the strong phytogeographic isolation of Sardegna highlighted by Peruzzi et al. [185] and Abbate et al. [186], and the relative isolation of Puglia with respect to other southern Italian peninsular regions found by Peruzzi et al. [185]. This evidence suggest that the reliable evaluation of the floristic similarities between different areas (regions, countries, etc.) is only possible with complete data (i.e., all species and subspecies) on vascular flora.

We have found that only 310 taxa $(4.11 \%)$ are common to all regions, while 2141 $(28.37 \%)$ result exclusively present in a single administrative Italian region. Almost half of this 2141 native taxa (i.e., 1026 taxa) are classified as regional endemic [33] with a restricted range and therefore worthy of protection [47]. Notable examples are: Armeria helodes (Friuli-Venezia Giulia), Astragalus siculus (Sicilia), Athamanta cortiana (Toscana), Campanula elatines (Piemonte), Campanula reatina (Lazio), Centaurea leucadea (Puglia), Genista tenorei (Basilicata), Hieracium semicanescens (Emilia-Romagna), Linaria tonzigii (Lombardia), Lonicera stabiana (Campania), Moehringia papulosa (Marche), Nigritella buschmanniae (Trentino-Alto Adige), Pilosella sciadogena (Umbria), Pinguicula lattanziae (Liguria), Poa magellensis (Abruzzo), Polygala sardoa (Sardegna), Ranunculus bovioi (Valle d'Aosta), Saxifraga berica (Veneto) and Soldanella calabrella (Calabria). More generally, the northernmost regions are mostly characterized by Alpine endemics and Central or Orophyte European taxa such as Alchemilla helvetica, Artemisia glacialis, Dianthus furcatus subsp. lereschii, Euphrasia alpina 
subsp. christii, Hornungia alpina subsp. austroalpina, Jacobaea alpina, Pedicularis rosea subsp. allionii, Sabulina austriaca, Sempervivum glaucum, Soldanella minima, Taraxacum venustum, Trisetaria alpestris and Valeriana celtica subsp. celtica. On the contrary, the native flora of the southern regions is more characterized by South Italian endemic taxa and with Mediterranean distribution such as Carex panormitana, Crepis rubra, Genista etnensis, Lathyrus jordanii, Rumex scutatus subsp. glaucescens, Sabulina verna subsp. grandiflora, Saponaria sicula and Stipa austroitalica subsp. austroitalica (Table S5).

As is known, latitude is not an ecological factor directly affecting plant diversity [187]. In accordance with Kessler et al. [188], numerous ecological factors (e.g., climatic and soil characteristics) that vary with latitude may be responsible for creating latitudinal diversity patterns in Italy. Our results at the regional level suggest that the higher values of richness and density of native taxa can be correlated to the environmental diversification of the same regions. Nowadays, it is mainly the wet areas and the presence of islands and mountain massifs that determine a greater plant diversity. Factors directly related to elevation (e.g., temperature, rainfall, light intensity, nitrogen availability) are indicated as the main factors that regulate the distribution and number of taxa $[189,190]$. Despite most of the studies on species richness variation along elevational gradients found either a monotonic decline with increasing elevation or a hump-shaped pattern with a mid-elevational peak [191-193], the presence of high mountains favors the processes of plant speciation. Indeed, in recent years, many species were discovered or described for mountain areas also in Italy [194-196].

Instead, analyzing the effect of the alien flora alone, the presence of two large groups of regions are highlighted both in the dendrogram (Figure 5B) and in the biblot (Figure 5E); one includes only the continental regions (except Valle d'Aosta and Liguria), and the other all the other regions. In other words, the alien taxa currently present in continental Italy are, at least in part, different from those found in the rest of Italy including the islands. Indeed, of the 1603 exotic reported at national level only $35(2.18 \%)$ are reported in all Italian regions such as Ailanthus altissima (Mill.) Swingle, Datura stramonium L., Erigeron sumatrensis Retz., Robinia pseudoacacia L. and Sorghum halepense (L.) Pers. In addition, all northern regions (except Valle d'Aosta and Liguria) are distinguished from others by only four exclusive alien taxa that are Bidens lanceolata, Elodea nuttallii, Spiraea salicifolia and Sporobolus neglectus (Table S5). All these data also confirm our hypothesis regarding an increase in similarities between regions due to the introduction of non-native species. However, these results are surprising because one would expect a greater similarity between the alien floras of each region. In fact, it is known that non-native taxa can promote homogenization in living systems all over the world [197]. Fortunately, although some regions show a large rate of alien taxa (see Table 2 and Figure 3), the presence of exotics did not alter the ability to distinguish the regions on the basis of their total flora (Figure 5C,F). This pattern of plant distribution in the Italian regions would seem to indicate the presence of a strong phytoclimatic driver (e.g., greater extension and intensity of the Mediterranean climate in the southern regions), which influences the overall similarity between the regional floras, largely overcoming historical factors, and shaping the North-South clustering of regions along the Italian Peninsula.

Regarding the new regional floristic index (RFI) proposed by us here, we point out that its range (i.e., the difference between the maximum and minimum value) resulted significantly greater when applied to only regional alien taxa (FRI $a$ ) compared to only native taxa (FRIn) (i.e., 1.524 vs. 0.542). These results suggest that, at least in the richest (Trentino-Alto Adige for aliens and Toscana for natives) and poorest regions (Valle d'Aosta both for aliens and natives) of taxa, the alien component contributes more than the native one to sharpen the differences between regions. As new introductions of alien species are expected to increase in the coming years [198], this gap will likely widen.

\section{Conclusions}

As far as we know, Italy is the only country in the Mediterranean basin that has continuously updated floristic knowledge at the regional level. Our study represents a 
step towards a better understanding of its floristic diversity. The data obtained confirm the important role of floristic investigations in the field and in herbaria, as well as the collaborative approach among botanists. Overall, we recorded or confirmed, for the first time in Italy and Europe, four alien vascular plant taxa, including Oxalis brasiliensis cited as historically present in Italy based on herbarium samples. On the contrary, no major native species (i.e., floristic novelties) for the Italian vascular flora were found by us in the field or in the herbaria consulted. Analysis of the data thus allowed us to update the number of plant taxa present in Italy today (which amount to 7547 native and 1603 exotic taxa) and to evaluate the degree of floristic similarity between administrative regions. We found that the regional floras have a clear distribution along the latitudinal gradient and this pattern is not affected by the introduction of alien species. On the basis of the available literature, this appears to be the first study that statistically analyzed the similarities between the Italian regions considering separately the native, alien and total vascular plants currently occurring in these areas.

The next step should be to improve the knowledge on the distribution of taxa through the georeferencing of occurrences. This information will be useful to better define the areas richest in taxa and to investigate the drivers related to the plant distribution patterns in Italy. However, we believe that several problems will have to be addressed by botanists in the coming years. Among these, there is certainly the need to standardize the methods for attributing invasive status to taxa found outside their original range. Additionally, given the taxonomic problems highlighted by many authors for several critical groups, further studies are required to properly assess the floristic composition of Italian vascular flora.

Supplementary Materials: The following are available online at https://www.mdpi.com/article/10 $.3390 / \mathrm{d} 13110600 / \mathrm{s} 1$, Table S1: Details on the collected floristic data (i.e., exsiccata and observata), Table S2: Exclusive endemic taxa of a single Italian region, Table S3: Values of Ren, Rea, Dtn, Dta, DN $t n, \mathrm{DN} t a$ and Ree for each region, Table S4: Values of RFI $n$, RFI $a$ and RFI for each region, Table S5: List of the exclusive native and alien taxa of the main clusters groups in the dendrograms of the agglomerative hierarchical clustering.

Author Contributions: Conceptualization, A.S.; methodology, A.S.; software, A.S.; formal analysis, A.S.; investigation, A.S., C.M.M., L.R., V.L.A.L., W.L., E.F., R.P.W., G.G., S.F., A.E., T.F., G.N., G.C. (Giuseppina Chianese), G.C. (Giampiero Ciaschetti), G.S., P.F., R.D.P., E.V.P., C.A., L.D.S. and G.M.; data curation, A.S., C.M.M., L.R., V.L.A.L., W.L., E.F., R.P.W., G.G., S.F., A.E., T.F., G.N., G.C. (Giuseppina Chianese), G.C. (Giampiero Ciaschetti), G.S., P.F., R.D.P., E.V.P., C.A., L.D.S. and G.M.; writing—original draft preparation, A.S.; writing—review and editing, A.S., C.M.M., L.R., E.F., G.G., R.P.W., S.F., A.E., G.C. (Giampiero Ciaschetti), P.F. and G.M. All authors have read and agreed to the published version of the manuscript.

Funding: This research received no external funding.

Institutional Review Board Statement: Not applicable.

Informed Consent Statement: Not applicable.

Data Availability Statement: The data used in the study can be obtained upon request from a corresponding author. The data is not publicly available due to its usage in the ongoing study.

Acknowledgments: The authors are grateful to the directors and curators of the cited herbaria for facilitating the consultation of samples, and to the anonymous reviewers for their suggestions that allowed us to improve and make the manuscript much clearer. A.S. wishes also to thank Giulio Ferretti (Department of Biology, University of Firenze, Italy) for confirming the absence of Oxalis brasiliensis in Toscana, as well as Mauro Rossi and Daniela Castaldi (Library of the Department of Environmental, Biological and Pharmaceutical Sciences and Technologies, University of Campania Luigi Vanvitelli, Italy) for providing many scientific papers.

Conflicts of Interest: The authors declare no conflict of interest.

\section{References}

1. Pignatti, S. Flora d'Italia 1-3; Edagricole: Bologna, Italy, 1982. 
2. Arcangeli, G. Compendio Della Flora Italiana; Ermanno Loercher: Torino, Italy, 1882.

3. Arcangeli, G. Compendio Della Flora Italiana, 2nd ed.; Ermanno Loercher: Torino, Italy, 1894.

4. Cesati, V.; Passerini, G.; Gibelli, G. Compendio della Flora Italiana 1-2; Dott. Francesco Villardi Tipografo-Editore: Milano, Italy, 1868-1886.

5. Fiori, A.; Paoletti, G. Flora Analitica d'Italia 1-4; Tipografia del Seminario: Padova, Italy, 1896-1908.

6. Fiori, A. Nuova Flora Analitica d'Italia 1-2; Tipografia M. Ricci: Firenze, Italy, 1923-1929.

7. Zangheri, P. Flora Italica 1-2; Cedam: Padova, Italy, 1976.

8. Bertoloni, A. Flora Italica 1-10; Typographaeo Richardi Masii: Bononiae, Italy, 1833-1854.

9. Parlatore, F. Flora Italiana 1-5; Tipografia Le Monnier: Firenze, Italy, 1848-1875.

10. Parlatore, F.; Caruel, T. Flora Italiana 6-10; Tipografia Le Monnier: Firenze, Italy, 1874-1896.

11. Gottschlich, G. Hieracium boreoapenninum Gottschl. (Compositae), a new species from the Northern Apennine (Italy). Webbia 2009, 64, 3-7. [CrossRef]

12. Bacchetta, G.; Brullo, S.; Salmeri, C. Hypericum scruglii sp. nov. (Guttiferae) from Sardinia. Nord. J. Bot. 2010, 28, 469-474. [CrossRef]

13. Conti, F. A new species of Lathyrus L. (Fabaceae) from Central Apennine (Italy). Plant Biosyst. 2010, 144, 814-818. [CrossRef]

14. Brullo, S.; Tomaselli, V.; Wagensommer, R.P. A new species of Odontites (Orobanchaceae) from southern Italy. Phytotaxa 2015, 213, 271-281. [CrossRef]

15. Di Pietro, R. Taxonomic Features of Sesleria calabrica (Poaceae), a Neglected Species from Southern Italy. Folia Geobot. 2007, 42, 289-313. [CrossRef]

16. Conti, F.; Giordano, C.; Moraldo, B.; Riccieri, C. Contributions to the Taxonomy of the Italian and Northern Balkanic Taxa in the Centaurea rupestris Group (Asteraceae). Ann. Bot. Fenn. 2011, 48, 193-218. [CrossRef]

17. Dunkel, F.G. The Ranunculus auricomus L. complex (Ranunculaceae) in Central and Southern Italy, with additions to North Italian taxa. Webbia 2011, 66, 165-193. [CrossRef]

18. Iamonico, D. Taxonomic revision of the genus Amaranthus (Amaranthaceae) in Italy. Phytotaxa 2015, 199, 1-84. [CrossRef]

19. Brullo, S.; Sciandrello, S. Cyperus alopecuroides Rottb. (Cyperaceae): Typification and first record for Sicily. Candollea 2006, 61, 365-372.

20. Stinca, A.; Pignatti, S. A new combination in Smyrnium (Apiaceae). Phytotaxa 2016, 284, 137. [CrossRef]

21. Banfi, E.; Galasso, G.; Bartolucci, F. Nomenclatural novelties for the Euro+Med flora. Nat. Hist. Sci. 2018, 5, 53-57. [CrossRef]

22. Ito, Y.; Ohi-Toma, T.; Nepi, C.; Santangelo, A.; Stinca, A.; Tanaka, N.; Murata, J. Towards a better understanding of the Ruppia maritima complex (Ruppiaceae): Notes on the correct application and typification of the names R. cirrhosa and $R$. spiralis. Taxon 2017, 66, 167-171. [CrossRef]

23. Wagensommer, R.P. Lectotypification of the name Genista michelii (Fabaceae). Phytotaxa 2017, 309, 99-100. [CrossRef]

24. Conti, F.; Bartolucci, F.; Manzi, A.; Paolucci, M.; Santucci, B.; Petriccione, B.; Miglio, M.; Ciaschetti, G.; Stinca, A. Integrazioni alla flora vascolare dell'Italia Centrale. Atti Soc. Toscana Sci. Nat. Mem. Ser. B 2016, 122, 33-42. [CrossRef]

25. Salerno, G.; Stinca, A. First European record of Solandra maxima (Sessé \& Moc.) P.S.Green (Solanaceae). Ann. di Bot. 2017, 7, 67-70. [CrossRef]

26. Wagensommer, R.P.; Bartolucci, F.; Fiorentino, M.; Licht, W.; Peccenini, S.; Perrino, E.V.; Venanzoni, R. First record for the flora of Italy and lectotypification of the name Linum elegans (Linaceae). Phytotaxa 2017, 296, 161-170. [CrossRef]

27. Stinca, A.; Mei, G. Ehrharta erecta (Poaceae, Ehrhartoideae): Distribution in Italy and taxonomy of one of the most invasive plant species in the world. BioInvasions Rec. 2019, 8, 742-752. [CrossRef]

28. Pignatti, S.; Guarino, R.; La Rosa, M. Flora d'Italia 1; Edagricole: Bologna, Italy, 2017.

29. Pignatti, S.; Guarino, R.; La Rosa, M. Flora d'Italia 2; Edagricole: Bologna, Italy, 2017.

30. Pignatti, S.; Guarino, R.; La Rosa, M. Flora d'Italia 3; Edagricole: Bologna, Italy, 2018.

31. Pignatti, S.; Guarino, R.; La Rosa, M. Flora d'Italia 4; Edagricole: Bologna, Italy, 2019.

32. Khandani, S.; Assadi, M.; Nejadsatari, T.; Mehregan, I. Phenetic analysis of the genera medicagoid Trigonella, Medicago and Melilotus (Fabaceae) on seed coat in Iran. Biodiversitas 2016, 17, 162-171. [CrossRef]

33. Bartolucci, F.; Peruzzi, L.; Galasso, G.; Albano, A.; Alessandrini, A.; Ardenghi, N.M.G.; Astuti, G.; Bacchetta, G.; Ballelli, S.; Banfi, E.; et al. An updated checklist of the vascular flora native to Italy. Plant Biosyst. 2018, 152, 179-303. [CrossRef]

34. Galasso, G.; Conti, F.; Peruzzi, L.; Ardenghi, N.M.G.; Banfi, E.; Celesti-Grapow, L.; Albano, A.; Alessandrini, A.; Bacchetta, G.; Ballelli, S.; et al. An updated checklist of the vascular flora alien to Italy. Plant Biosyst. 2018, 152, 556-592. [CrossRef]

35. Perrino, E.V.; Silletti, G.N.; Erben, M.; Wagensommer, R.P. Viola cassinensis subsp. lucana (Violaceae), a new subspecies from the Lucanian Apennine, southern Italy. Phyton 2018, 58, 109-115. [CrossRef]

36. Rosati, L.; Coppi, A.; Farris, E.; Fascetti, S.; Becca, G.; Peregrym, M.; Tan, K.; Selvi, F. The genus Gymnospermium (Berberidaceae) in Italy: Identity and relationships of the populations at the western limit of the genus range. Plant Biosyst. 2019, 153, 796-808. [CrossRef]

37. Sciandrello, S.; Galdo, G.; Salmeri, C.; Minissale, P. Vicia brulloi (Fabaceae), a new species from Sicily. Phytotaxa 2019, 418, 57-78. [CrossRef]

38. Stinca, A.; Esposito, A. Typification of the name Stachys recta subsp. tenoreana (Lamiaceae). Phytotaxa 2019, 419, 110-112. [CrossRef] 
39. Stinca, A.; Conti, F.; Bartolucci, F. Typification of the name Centaurea deusta Ten. (Asteraceae). Phytotaxa 2019, 399, $296-299$. [CrossRef]

40. Musarella, C.M. Solanum torvum Sw. (Solanaceae): A new alien species for Europe. Genet. Resour. Crop Evol. 2020, 67, 515-522. [CrossRef]

41. Rosati, L.; Fascetti, S.; Romano, V.A.; Potenza, G.; Lapenna, M.R.; Capano, A.; Nicoletti, P.; Farris, E.; de Lange, P.J.; Del Vico, E.; et al. New Chorological Data for the Italian Vascular Flora. Diversity 2020, 12, 22. [CrossRef]

42. Stinca, A. Brugmansia suaveolens (Humb. \& Bonpl. Ex Willd.) Sweet (Solanaceae): An alien species new to continental Europe. BioInvasions Rec. 2020, 9, 660-669. [CrossRef]

43. Conti, F.; Bartolucci, F. Anthyllis apennina (Fabaceae), a new species from central Apennine (Italy). PhytoKeys 2021, 176, 111-129. [CrossRef]

44. Di Pietro, R.; Kuzmanović, N.; Lakušić, D.; Viciani, D.; Fortini, P.; Iamonico, D. Nomenclatural and taxonomic notes on some names of Sesleria sect. Argenteae (Poaceae) from Italy and the Balkans. Phytotaxa 2021, 494, 89-102. [CrossRef]

45. Wagensommer, R.P.; Venanzoni, R. Geranium lucarinii sp. nov. and re-evaluation of G. kikianum (Geraniaceae). Phytotaxa 2021, 489, 252-262. [CrossRef]

46. Bartolucci, F.; Galasso, G.; Peruzzi, L.; Conti, F. Report 2020 on plant biodiversity in Italy: Native and alien vascular flora. Nat. Hist. Sci. 2021, 8, 41-54. [CrossRef]

47. Orsenigo, S.; Montagnani, C.; Fenu, G.; Gargano, D.; Peruzzi, L.; Abeli, T.; Alessandrini, A.; Bacchetta, G.; Bartolucci, F.; Bovio, M.; et al. Red Listing plants under full national responsibility: Extinction risk and threats in the vascular flora endemic to Italy. Biol. Conserv. 2018, 224, 213-222. [CrossRef]

48. Stinca, A.; Chianese, G.; D’Auria, G.; Fascetti, S.; Ravo, M.; Romano, V.A.; Salerno, G.; Astuti, G.; Bartolucci, F.; Bernardo, L.; et al. Contribution to the floristic knowledge of eastern Irpinia and Vulture-Melfese area (Campania and Basilicata, southern Italy). Ital. Bot. 2019, 8, 1-16. [CrossRef]

49. Scoppola, A.; Blasi, C. (Eds.) Stato Delle Conoscenze Sulla Flora Vascolare d'italia; Palombi Editori: Roma, Italy, 2005.

50. Williams, N.S.G.; Morgan, J.W.; Mcdonnell, M.J.; Mccarthy, M.A. Plant traits and local extinctions in natural grasslands along an urban-rural gradient. J. Ecol. 2005, 93, 1203-1213. [CrossRef]

51. Hahs, A.K.; McDonnell, M.J.; McCarthy, M.A.; Vesk, P.A.; Corlett, R.T.; Norton, B.A.; Clemants, S.E.; Duncan, R.P.; Thompson, K.; Schwartz, M.W.; et al. A global synthesis of plant extinction rates in urban areas. Ecol. Lett. 2009, 12, 1165-1173. [CrossRef] [PubMed]

52. Motti, R.; Zotti, M.; Bonanomi, G.; Cozzolino, A.; Stinca, A.; Migliozzi, A. Climatic and anthropogenic factors affect Ailanthus altissima invasion in a Mediterranean region. Plant Ecol. 2021, 222, 1347-1359. [CrossRef]

53. Salinitro, M.; Alessandrini, A.; Zappi, A.; Tassoni, A. Impact of climate change and urban development on the flora of a southern European city: Analysis of biodiversity change over a 120-year period. Sci. Rep. 2019, 9, 9464. [CrossRef]

54. Mihoub, J.B.; Henle, K.; Titeux, N.; Brotons, L.; Brummitt, N.A.; Schmeller, D.S. Setting temporal baselines for biodiversity: The limits of available monitoring data for capturing the full impact of anthropogenic pressures. Sci. Rep. 2017, 7, 41591. [CrossRef] [PubMed]

55. Myers, N.; Mittermeier, R.A.; Mittermeier, C.G.; da Fonseca, G.A.B.; Kent, J. Biodiversity hotspots for conservation priorities. Nature 2000, 403, 853-858. [CrossRef]

56. Tarquini, S.; Isola, I.; Favalli, M.; Battistini, A. TINITALY, a Digital Elevation Model of Italy with a 10 Meters Cell Size (Version 1.0) [Data Set]; Istituto Nazionale di Geofisica e Vulcanologia (INGV). Available online: https:/ / doi.org/10.13127/TINITALY/1.0 (accessed on 29 October 2021).

57. ISTAT. Popolazione Residente al $1^{\circ}$ Gennaio; National Institute of Statistics. Available online: http://dati.istat.it/Index.aspx? QueryId=18460 (accessed on 15 September 2021).

58. Rivas-Martínez, S.; Penas, Á.; Díaz, T.E. Bioclimatic E Biogeographic Maps of Europe. Available online: http://www. globalbioclimatics.org/form/maps.htm (accessed on 7 September 2021).

59. Thiers, B. Index Herbariorum: A Global Directory of Public Herbaria. New York Botanical Garden's Virtual Herbarium. Available online: http:/ / sweetgum.nybg.org/ih/ (accessed on 15 September 2021).

60. Bartolucci, F.; Domina, G.; Ardenghi, N.M.G.; Banfi, E.; Bernardo, L.; Bonari, G.; Buccomino, G.; Calvia, G.; Carruggio, F.; Cavallaro, V.; et al. Notulae to the Italian native vascular flora: 5. Ital. Bot. 2018, 5, 71-81. [CrossRef]

61. Bartolucci, F.; Domina, G.; Ardenghi, N.M.G.; Bacchetta, G.; Bernardo, L.; Buccomino, G.; Buono, S.; Caldararo, F.; Calvia, G.; Carruggio, F.; et al. Notulae to the Italian native vascular flora: 6. Ital. Bot. 2018, 6, 45-64. [CrossRef]

62. Bartolucci, F.; Domina, G.; Alessandrini, A.; Angiolini, C.; Ardenghi, N.M.G.; Bacchetta, G.; Banfi, E.; Bolpagni, R.; Bonari, G.; Bräuchler, C.; et al. Notulae to the Italian native vascular flora: 7. Ital. Bot. 2019, 7, 125-148. [CrossRef]

63. Bartolucci, F.; Domina, G.; Ardenghi, N.M.G.; Bacaro, G.; Bacchetta, G.; Ballarin, F.; Banfi, E.; Barberis, G.; Beccarisi, L.; Bernardo, L.; et al. Notulae to the Italian native vascular flora: 8. Ital. Bot. 2019, 8, 95-116. [CrossRef]

64. Bartolucci, F.; Domina, G.; Andreatta, S.; Angius, R.; Ardenghi, N.M.G.; Bacchetta, G.; Ballelli, S.; Banfi, E.; Barberis, D.; Barberis, G.; et al. Notulae to the Italian native vascular flora: 9. Ital. Bot. 2020, 9, 71-86. [CrossRef]

65. Bartolucci, F.; Domina, G.; Bagella, S.; Barberis, G.; Briozzo, I.; Calbi, M.; Caria, M.C.; Cavallaro, V.; Chianese, G.; Cibei, C.; et al. Notulae to the Italian native vascular flora: 10. Ital. Bot. 2020, 10, 47-55. [CrossRef] 
66. Bartolucci, F.; Domina, G.; Andreatta, S.; Argenti, C.; Bacchetta, G.; Ballelli, S.; Banfi, E.; Barberis, D.; Barberis, G.; Bedini, G.; et al. Notulae to the Italian native vascular flora: 11. Ital. Bot. 2021, 11, 77-92. [CrossRef]

67. Galasso, G.; Domina, G.; Adorni, M.; Ardenghi, N.M.G.; Bonari, G.; Buono, S.; Cancellieri, L.; Chianese, G.; Ferretti, G.; Fiaschi, T.; et al. Notulae to the Italian alien vascular flora: 5. Ital. Bot. 2018, 5, 45-56. [CrossRef]

68. Galasso, G.; Domina, G.; Alessandrini, A.; Ardenghi, N.M.G.; Bacchetta, G.; Ballelli, S.; Bartolucci, F.; Brundu, G.; Buono, S.; Busnardo, G.; et al. Notulae to the Italian alien vascular flora: 6. Ital. Bot. 2018, 6, 65-90. [CrossRef]

69. Galasso, G.; Domina, G.; Ardenghi, N.M.G.; Aristarchi, C.; Bacchetta, G.; Bartolucci, F.; Bonari, G.; Bouvet, D.; Brundu, G.; Buono, S.; et al. Notulae to the Italian alien vascular flora: 7. Ital. Bot. 2019, 7, 157-182. [CrossRef]

70. Galasso, G.; Domina, G.; Andreatta, S.; Angiolini, C.; Ardenghi, N.M.G.; Aristarchi, C.; Arnoul, M.; Azzella, M.M.; Bacchetta, G.; Bartolucci, F.; et al. Notulae to the Italian alien vascular flora: 8. Ital. Bot. 2019, 8, 63-93. [CrossRef]

71. Galasso, G.; Domina, G.; Adorni, M.; Angiolini, C.; Apruzzese, M.; Ardenghi, N.M.G.; Assini, S.; Aversa, M.; Bacchetta, G.; Banfi, E.; et al. Notulae to the Italian alien vascular flora: 9. Ital. Bot. 2020, 9, 47-70. [CrossRef]

72. Galasso, G.; Domina, G.; Azzaro, D.; Bagella, S.; Barone, G.; Bartolucci, F.; Bianco, M.; Bolzani, P.; Bonari, G.; Boscutti, F.; et al. Notulae to the Italian alien vascular flora: 10. Ital. Bot. 2020, 10, 57-71. [CrossRef]

73. Galasso, G.; Domina, G.; Andreatta, S.; Argenti, E.; Bacchetta, G.; Bagella, S.; Banfi, E.; Barberis, D.; Bardi, S.; Barone, G.; et al. Notulae to the Italian alien vascular flora: 11. Ital. Bot. 2021, 11, 93-119. [CrossRef]

74. Martellos, S.; Bartolucci, F.; Conti, F.; Galasso, G.; Moro, A.; Pennesi, R.; Peruzzi, L.; Pittao, E.; Nimis, P.L. FlorItaly-The portal to the Flora of Italy. PhytoKeys 2020, 156, 55-71. [CrossRef] [PubMed]

75. Tutin, T.G.; Heywood, V.H.; Burges, N.A.; Moore, D.M.; Valentine, D.H.; Walters, S.M.; Webb, D.A. (Eds.) Flora Europaea 2; Cambridge University Press: Cambridge, UK, 1968.

76. Tutin, T.G.; Heywood, V.H.; Burges, N.A.; Moore, D.M.; Valentine, D.H.; Walters, S.M.; Webb, D.A. (Eds.) Flora Europaea 3; Cambridge University Press: Cambridge, UK, 1972.

77. Tutin, T.G.; Heywood, V.H.; Burges, N.A.; Moore, D.M.; Valentine, D.H.; Walters, S.M.; Webb, D.A. (Eds.) Flora Europaea 4; Cambridge University Press: Cambridge, UK, 1976.

78. Tutin, T.G.; Heywood, V.H.; Burges, N.A.; Moore, D.M.; Valentin, E.D.H.; Walters, S.M.; Webb, D.A. (Eds.) Flora Europaea 5; Cambridge University Press: Cambridge, UK, 1980.

79. Tutin, T.G.; Burges, N.A.; Chater, A.O.; Edmondson, J.R.; Heywood, V.H.; Moore, D.M.; Valentine, D.H.; Walters, S.M.; Webb, D.A. (Eds.) Flora Europaea 1, 2nd ed.; Cambridge University Press: Cambridge, UK, 1993.

80. Flora of North America. Available online: http:/ / www.efloras.org/flora_page.aspx?flora_id=1 (accessed on 10 September 2021).

81. Flora of China. Available online: http://www.efloras.org/flora_page.aspx?flora_id=2 (accessed on 10 September 2021).

82. Flora do Brasil 2020. Available online: http:/ / floradobrasil.jbrj.gov.br/ (accessed on 10 September 2021).

83. POWO. Plants of the World Online. Facilitated by the Royal Botanic Gardens, Kew. Available online: http://www. plantsoftheworldonline.org/ (accessed on 20 September 2021).

84. Pyšek, P.; Richardson, D.M.; Rejmánek, M.; Webster, G.L.; Williamson, M.; Kirschner, J. Alien plants in checklists and floras: Towards better communication between taxonomists and ecologists. Taxon 2004, 53, 131-143. [CrossRef]

85. Addinsoft 2021. XLSTAT Version 2021.3.1. Available online: https:/ /www.xlstat.com/en/ (accessed on 15 September 2021).

86. Ricciardi, M. Flora di Capri (Golfo di Napoli). Ann. Bot. 1998, 54, 7-169.

87. Ricciardi, M.; Nazzaro, R.; Caputo, G.; De Natale, A.; Vallariello, G. The flora of the Island of Ischia (Bay of Naples). Webbia 2004, 59, 1-113. [CrossRef]

88. Motti, R.; Ricciardi, M. The flora of the Phlegrean Fields (Gulf of Pozzuoli, Campania, Italy). Webbia 2005, 60, 395-476. [CrossRef]

89. Stinca, A.; Motti, R. The vascular flora of the Royal Park of Portici (Naples, Italy). Webbia 2009, 64, 235-266. [CrossRef]

90. Anzalone, B.; Iberite, B.; Lattanzi, E. La Flora vascolare del Lazio. Inform. Bot. Ital. 2010, 41, 187-317.

91. Salerno, G. Segnalazioni Floristiche Italiane: 1010. Inform. Bot. Ital. 2001, 33, 37.

92. De Natale, A. Note floristiche per il Parco Nazionale del Cilento e Vallo di Diano (Salerno, Campania). Inform. Bot. Ital. 2004, 36, 29-33.

93. Stinca, A.; D'Auria, G.; Salerno, G.; Motti, R. Ulteriori integrazioni alla flora vascolare aliena della Campania (Sud Italia). Inform. Bot. Ital. 2013, 45, 71-81.

94. Del Guacchio, E.; Magri, B. Notulae alla checklist della Flora vascolare Italiana 2: 1215. Inform. Bot. Ital. $2006,38,197$.

95. Nicolella, G. Noterella 0139. Acta Plant. Notes 2015, 3, 78.

96. Lucchese, F. Atlante Della Flora Vascolare Del Lazio: Cartografia, Ecologia e Biogeografia. Vol. 1: Parte Generale e Flora Alloctona; Regione Lazio, Direzione Capitale Naturale, Parchi e Aree Protette: Roma, Italy, 2017.

97. Parrella, G.; Greco, B.; Cennamo, G.; Griffo, R.; Stinca, A. Araujia sericifera new Host of Alfalfa mosaic virus in Italy. Plant Dis. 2013, 97, 1387. [CrossRef]

98. Crisafulli, A.; Cannavò, S.; Maiorca, G.; Musarella, C.M.; Signorino, G.; Spampinato, G. Aggiornamenti floristici per la Calabria. Inform. Bot. Ital. 2010, 42, 437-448.

99. Tison, J.-M.; de Foucault, B. Flora Gallica. Flore de France; Biotope: Mèze, France, 2014.

100. Pirone, G.; Ciaschetti, G.; Di Martino, L.; Cianfaglione, K.; Giallonardo, T.; Frattaroli, A.R. Contribution to the knowledge of the coastal vegetation of Abruzzo (central Adriatic). Plant Sociol. 2014, 51 (Suppl. 1), 57-64. [CrossRef] 
101. Laface, V.L.A.; Musarella, C.M.; Cano Ortiz, A.; Quinto Canas, R.; Cannavò, S.; Spampinato, G. Three New Alien Taxa for Europe and a Chorological Update on the Alien Vascular Flora of Calabria (Southern Italy). Plants 2020, 9, 1181. [CrossRef]

102. Lattanzi, E.; Tondi, G.; Di Pietro, R. Segnalazioni Floristiche Italiane: 909. Inform. Bot. Ital. 1998, 30, 64.

103. Roma-Marzio, F.; D’Antraccoli, M.; Angeloni, D.; Bartolucci, F.; Bernardo, L.; Cancellieri, L.; Caruso, G.; Conti, F.; Dolci, D.; Gestri, G.; et al. Contribution to the floristic knowledge of Sillaro, Santerno, and Senio high valleys (Toscana, Italy). Ital. Bot. 2020, 10, 101-111. [CrossRef]

104. Valdés, B. Boraginaceae. In Euro+Med Plantbase; Available online: http://ww2.bgbm.org/euroPlusMed/query.asp. (accessed on 10 September 2021).

105. Wagensommer, R.P.; Fröhlich, T.; Fröhlich, M. First record of the southeast European species Cerinthe retorta Sibth. (Boraginaceae) in Italy and considerations on its distribution and conservation status. Acta Bot. Gall. 2014, 161, 111-115. [CrossRef]

106. Karl, R.; Scholz, H. Med-Checklist Notulae, 28. Willdenowia 2009, 39, 335-345. [CrossRef]

107. Wagensommer, R.P.; Perrino, E.V.; Silletti, G.N. Carex phyllostachys C.A. Mey. (Cyperaceae) new for Italy and phytogeographical considerations. Phyton 2014, 54, 215-222. [CrossRef]

108. Terlevic, A.; Koopman, J.; Wieclaw, H.; Rešetnik, I.; Bogdanovic, S. Carex phyllostachys (Cyperaceae), a new species in Croatia. Acta Bot. Croat. 2021, 80, 106-111. [CrossRef]

109. Fenu, G.; Bernardo, L.; Calvo, R.; Cortis, P.; De Agostini, A.; Gangale, C.; Gargano, D.; Gargano, M.L.; Lussu, M.; Medagli, P.; et al. Global and regional IUCN Red List assessments: 8. Ital. Bot. 2019, 8, 17-33. [CrossRef]

110. Peruzzi, L.; Bedini, G. (Eds.) Wikiplantbase \#Toscana v2.1. Available online: http://bot.biologia.unipi.it/wpb/toscana/index.html (accessed on 30 September 2021).

111. Rojas-Sandoval, J.; Acevedo-Rodríguez, P. Cyperus rotundus . In Invasive Species Compendium; CAB International: Wallingford, UK; Available online: https://www.cabi.org/isc/datasheet/17506\#todistribution (accessed on 1 November 2021).

112. Amphlett, A. Deschampsia Cespitosa Subsp. Parviflora (Poaceae)—An under-recorded woodland grass. Br. Ir. Bot. 2019, 1, 117-127. [CrossRef]

113. Wilhalm, T. Digitaria ciliaris in Europe. Willdenowia 2009, 39, 247-259. [CrossRef]

114. Di Pietro, R.; Izco, J.; Blasi, C. Contribution to the nomenclatural knowledge of Fagus sylvatica woodlands of southern Italy. Plant Biosyst. 2004, 138, 27-36. [CrossRef]

115. Di Pietro, R. Observations on the beech woodlands of the Apennines (peninsular Italy): An intricate biogeographical and syntaxonomical issue. Lazaroa 2009, 30, 89-97.

116. Todini, A. Considerazioni sulla presenza a Roma di Festuca drymeia M. et K., specie di nuova segnalazione nel Lazio. Inform. Bot. Ital. 1999, 31, 39-42.

117. Foggi, B.; Parolo, G.; Rossi, G.; Ardenghi, N.M.G.; Quercioli, C. Il genere Festuca e i generi affini per una flora critica dell'Italia. II. I generi Leucopoa e Drymochloa (Poaceae). Inform. Bot. Ital. 2010, 42, 335-361.

118. Croce, A.; Stinca, A.; Santangelo, A.; Esposito, A. Exploring vascular flora biodiversity of two protected sandy coastal areas in southern Italy. Rend. Fis. Acc. Lincei 2019, 30, 323-336. [CrossRef]

119. Mazzoleni, S.; Ricciardi, M. Boschi misti costieri in Campania. Ann. Bot. 1995, 51 (Suppl. 10), $279-296$.

120. POWO. Elaeodendron croceum (Thunb.) DC. Plants of the World Online. Facilitated by the Royal Botanic Gardens, Kew. Available online: http:/ / www.plantsoftheworldonline.org/taxon/urn:lsid:ipni.org:names:160659-1 (accessed on 20 September 2021).

121. Mugnai, M.; Lazzaro, L.; Di Nuzzo, L.; Foggi, B.; Viciani, D.; Ferretti, G. Synopsis of Euphorbia section Anisophyllum (Euphorbiaceae) in Italy, with an insight on variation of distribution over time in Tuscany. Phytotaxa 2021, 485, 1-65. [CrossRef]

122. Musarella, C.M.; Stinca, A.; Cano-Ortíz, A.; Laface, V.L.A.; Petrilli, R.; Esposito, A.; Spampinato, G. New data on the alien vascular flora of Calabria (southern Italy). Ann. Bot. 2020, 10, 55-66. [CrossRef]

123. Licht, W.; Wagensommer, R.P. Flora Vascolare Del Gargano e Delle Isole Tremiti. Chiavi Analitiche per la Determinazione; Biblioteca Verde del Parco Nazionale del Gargano, Claudio Grenzi Ed.: Foggia, Italy, 2020.

124. Fanfarillo, E.; Latini, L.; Iberite, M.; Bonari, G.; Nicolella, G.; Rosati, L.; Salerno, G.; Abbate, G. The segetal flora of winter cereals and allied crops in Italy: Species inventory with chorological, structural and ecological features. Plant Biosyst. 2020, 154, 935-946. [CrossRef]

125. Caputo, G.; La Valva, V.; Nazzaro, R.; Ricciardi, M. La flora della Penisola Sorrentina (Campania). Delpinoa 1994, 31-32, 3-97.

126. POWO. Hypericum $\times$ inodorum Mill. Plants of the World Online. Facilitated by the Royal Botanic Gardens, Kew. Available online: http:/ / www.plantsoftheworldonline.org/taxon/urn:lsid:ipni.org:names:433509-1 (accessed on 20 September 2021).

127. Iamonico, D. Note floristiche per la Basilicata. Delpinoa 2006, 48, 21-27.

128. Caruso, G.; Uzunov, D.; Gangale, C. Notulae alla checklist della Flora vascolare Italiana 4: 1215. 1410. Inform. Bot. Ital. 2007, 39, 433.

129. Stinca, A.; Chianese, G.; D'Auria, G.; Del Guacchio, E.; Fascetti, S.; Perrino, E.V.; Rosati, L.; Salerno, G.; Santangelo, A. New alien vascular species for the flora of southern Italy. Webbia 2017, 72, 295-301. [CrossRef]

130. Herrando-Moraira, S.; Vitales, D.; Nualart, N.; Gómez-Bellver, C.; Ibáñez, N.; Massó, S.; Cachón-Ferrero, P.; González-Gutiérrez, P.A.; Guillot, D.; Herrera, I.; et al. Global distribution patterns and niche modelling of the invasive Kalanchoe $\times$ houghtonii (Crassulaceae). Sci. Rep. 2020, 10, 3143. [CrossRef]

131. Tenore, M. Flora Napolitana 3; Stamperia Francese: Napoli, Italy, 1824-1829. 
132. Tenore, M. Flora Medica Universale e Particolare Della Provincia di Napoli; Corso delle Botaniche Lezioni. Tipografia del giornale Enciclopedico: Napoli, Italy, 1923.

133. Tenore, M. Sylloge Plantarum Vascularium Florae Napolitanae Hucusque Detectarum; Tipografia del Fibreno: Napoli, Italy, 1831.

134. Galasso, G.; Domina, G.; Adorni, M.; Ardenghi, N.M.G.; Banfi, E.; Bedini, G.; Bertolli, A.; Brundu, G.; Calbi, M.; Cecchi, L.; et al. Notulae to the Italian alien vascular flora: 1. Ital. Bot. 2016, 1, 17-37. [CrossRef]

135. Oliveri, N. Notulae alla flora esotica d'Italia 12: 271. Inform. Bot. Ital. 2015, 47, 77-90.

136. Romolini, R.; Souche, R. Ophrys d'Italia; Éd. Sococor: Saint-Martin-de-Londres, France, 2012.

137. Pezzetta, A. Le Orchidee del Molise. Giros Notizie 2015, 58, 71-87.

138. Horne, H.E.; Barger, T.W.; Nesom, G.L. Two South American species of Oxalis (Oxalidaceae) naturalised in Alabama and the USA, first report. Phytoneuron 2013, 54, 1-7.

139. Drapiez, F.M. Oxalis brasiliensis. Botanical Cabinet. In Encyclographie du Regne Vegetal; A L'Establissement Encyclographique: Bruxelles, Belgium, 1836; Volume 4, unpaged; Available online: https: / books.google.it/books?id=ZjfOOTG0tPkC\&printsec= frontcover\&hl=it\&source=gbs_ge_summary_r\&cad=0\#v=onepage\&q\&f=false (accessed on 20 September 2021).

140. Hildebrand, F. Lebensverhältnisse der Oxalisarten; Verlag Von Gustav Fischer: Jena, Germany, 1884; pp. 43-46. Available online: https:/ /books.google.it/books?id=WpM_AAAAYAAJ\&pg=PA96\&lpg=PA96\&dq=Lebensverhaeltnisse+der+Oxalisarten+1884 \&source=bl\&ots=4rF3UoX2Pj\&sig=47MYQtRvESd9J0zF8uNehwu1TGs\&hl=en\&ei=G8CJTtLpFoH10gHjzszFDw\&sa=X\&oi= book_result\&ct=result\&sqi=2\&redir_esc=y\#v=onepage\&q\&f=false (accessed on 20 September 2021).

141. IPNI. Oxalis brasiliensis G.Lodd. ex Drapiez. International Plant Names Index. The Royal Botanic Gardens, Kew, Harvard University Herbaria \& Libraries and Australian National Botanic Gardens. Available online: https://www.ipni.org/n/77209116-1 (accessed on 20 September 2021).

142. POWO. Oxalis brasiliensis G.Lodd. ex Drapiez. Plants of the World Online. Facilitated by the Royal Botanic Gardens, Kew. Available online: http:/ / www.plantsoftheworldonline.org/taxon/urn:lsid:ipni.org:names:374712-1 (accessed on 20 September 2021).

143. Jenny, R. The Botanical Cabinet. Lankesteriana 2008, 8, 43-52. [CrossRef]

144. Stinca, A. Oxalidaceae. In Flora d'Italia; Pignatti, S., Guarino, R., La Rosa, M., Eds.; Edagricole: Bologna, Italy, 2017; Volume 2, pp. 353-360.

145. Kadereit, J.W. Some suggestions on the geographical origin of the central, west and north European synanthropic species of Papaver L. Bot. J. Linn. Soc. 1990, 103, 221-231. [CrossRef]

146. Lu, L.; Wen, J.; Chen, Z. A combined morphological and molecular phylogenetic analysis of Parthenocissus (Vitaceae) and taxonomic implications. Bot. J. Linn. Soc. 2012, 168, 43-63. [CrossRef]

147. Moore, M.O.; Wen, J. Parthenocissus Planchon. In Flora of North America; 2016; Volume 12, pp. 16-18. Available online: http:/ / www.efloras.org/florataxon.aspx?flora_id=1\&taxon_id=124105 (accessed on 20 October 2021).

148. Motti, R.; Stinca, A. Analysis of the biodeteriogenic vascular flora at the Royal Palace of Portici in southern Italy. Int. Biodeterior. Biodegrad. 2011, 65, 1256-1265. [CrossRef]

149. Stinca, A.; Croce, A.; D’Auria, G.; Salerno, G.; Santangelo, A.; Rosati, L.; Motti, R. Nuovi dati sulla flora vascolare aliena della Campania (Sud Italia). Atti Soc. Toscana Sci. Nat. Mem. Ser. B 2016, 122, 89-110. [CrossRef]

150. Stinca, A.; Galasso, G.; Banfi, E. First Italian record of Paspalum notatum Flüggé (Poaceae) and its typification. Acta Bot. Croat. 2016, 75, 153-156. [CrossRef]

151. Spampinato, G.; Sciandrello, S.; Giusso Del Galdo, G.; Puglisi, M.; Tomaselli, V.; Cannavò, S.; Musarella, C.M. Contribution to the knowledge of Mediterranean wetland biodiversity: Plant communities of the Aquila Lake (Calabria, Southern Italy). Plant Sociol. 2019, 56, 53-68. [CrossRef]

152. Parrella, G.; Troiano, E.; Stinca, A.; Pozzi, M.I. Molecular and serological detection of Parietaria mottle virus in Phytolacca americana, a new host of the virus. Phytopathol. Mediterr. 2021, 60, 101-104. [CrossRef]

153. Ohba, H. Sedum Linnaeus. In Flora of North America; Oxford University Press: Oxford, UK, 2009; Volume 8, pp. 199-222. Available online: http:/ / www.efloras.org/florataxon.aspx?flora_id=1\&taxon_id=129989 (accessed on 20 October 2021).

154. Giardina, G.; Raimondo, F.M.; Spadaro, V. A catalogue of plants growing in Sicily. Bocconea 2007, 20 , 5-582.

155. Stinca, A.; D'Auria, G.; Motti, R. Sullo status invasivo di Bidens bipinnata, Phoenix canariensis, Pistia stratiotes e Tradescantia fluminensis in Campania (Sud Italia). Inform. Bot. Ital. 2012, 44, 295-299.

156. Stinca, A.; D’Auria, G.; Motti, R. Integrazioni alla flora vascolare aliena della Campania (Sud Italia). Inform. Bot. Ital. 2012, 44, 287-293.

157. Curti, L.; Lorenzoni, G.G.; Marchiori, S. Florula del Bacino del Lago di Lesina (Foggia). Mem. Biogeogr. Adriat. 1974,9 , 45-117.

158. Forte, L.; Cavallaro, V.; Pantaleo, F.; D'Amico, F.S.; Macchia, F. The vascular Flora of the "Bosco Isola” at Lesina (Foggia-Apulia). Fl. Medit. 2002, 12, 33-92.

159. Ardenghi, N.M.G.; Galasso, G.; Banfi, E.; Zoccola, A.; Foggi, B.; Lastrucci, L. A taxonomic survey of the genus Vitis L. (Vitaceae) in Italy, with special reference to Elba Island (Tuscan Archipelago). Phytotaxa 2014, 166, 163-198. [CrossRef]

160. Stinca, A. The genus Vitis L. (Vitaceae) in Campania (Southern Italy), with emphasis on alien units. Ann. di Bot. 2019, 9, 107-112. [CrossRef]

161. Del Guacchio, E.; De Natale, A.; Stinca, A. Notes to the non-native flora of Campania (Southern Italy). Atti Soc. Toscana Sci. Nat. Mem. Ser. B 2020, 127, 39-49. [CrossRef] 
162. Mei, G.; Šegota, V.; Stinca, A.; Vukelić, J.; Baričević, D.; Taffetani, F.; Alegro, A. Cystopteris dickieana R.Sim (Cystopteridaceae), a new fern in the continental Balkans flora. Plant Biosyst. 2021, 155, 1-4. [CrossRef]

163. González-Rodríguez, A.M.; Baruch, Z.; Palomo, D.; Cruz-Trujillo, G.; Jiménez, M.S.; Morales, D. Ecophysiology of the invader Pennisteum setaceum and three native grasses in the Canary Islands. Acta Oecol. 2010, 36, 248-254. [CrossRef]

164. Pasta, S.; Badalamenti, E.; La Mantia, T. Tempi e modi di un'invasione incontrastata: Pennisetum setaceum (Forssk.) Chiov. (Poaceae) in Sicilia. Nat. Sicil. 2010, 34, 487-525.

165. Lazzaro, L.; Bolpagni, R.; Buffa, G.; Gentili, R.; Lonati, M.; Stinca, A.; Acosta, A.T.R.; Adorni, M.; Aleffi, M.; Allegrezza, A.; et al. Impact of invasive alien plants on native plant communities and Natura 2000 habitats: State of the art, gap analysis and perspectives in Italy. J. Environ. Manag. 2020, 274, 111140. [CrossRef]

166. Dehnen-Schmutz, K.; Touza, J.; Perrings, C.; Williamson, M. A century of the ornamental plant trade and its impact on invasion success. Divers. Distrib. 2007, 13, 527-534. [CrossRef]

167. Arianoutsou, M.; Bazos, I.; Christopoulou, A.; Kokkoris, Y.; Zikos, A.; Zervou, S.; Delipetrou, P.; Cardoso, A.C.; Deriu, I.; Gervasini, E.; et al. Alien plants of Europe: Introduction pathways, gateways and time trends. PeerJ 2021, 9, e11270. [CrossRef]

168. Orsenigo, S.; Fenu, G.; Gargano, D.; Montagnani, C.; Abeli, T.; Alessandrini, A.; Bacchetta, G.; Bartolucci, F.; Carta, A.; Castello, M.; et al. Red list of threatened vascular plant species in Italy. Plant Biosyst. 2021, 155, 310-335. [CrossRef]

169. Rossi, G.; Orsenigo, S.; Gargano, D.; Montagnani, C.; Peruzzi, L.; Fenu, G.; Abeli, T.; Alessandrini, A.; Astuti, G.; Bacchetta, G.; et al. Lista Rossa Della Flora Italiana. 2 Endemiti e Altre Specie Minacciate; Ministero dell'Ambiente e della Tutela del Territorio e del Mare: Roma, Italy, 2020.

170. Fenu, G.; Abdelaal, M.; Bacchetta, G.; Bongiorni, L.; Cogoni, A.; Cortis, P.; Croce, A.; Fois, M.; Lussu, M.; Perrino, E.V.; et al. Global and Regional IUCN Red List Assessments: 6. Ital. Bot. 2018, 6, 31-44. [CrossRef]

171. Lang, P.L.M.; Willems, F.M.; Scheepens, J.F.; Burbano, H.A.; Bossdorf, O. Using herbaria to study global environmental change. New Phytol. 2019, 221, 110-122. [CrossRef] [PubMed]

172. López, A.; Sassone, A.B. The Uses of Herbaria in Botanical Research. A Review Based on Evidence From Argentina. Front. Plant Sci. 2019, 10, 1363. [CrossRef] [PubMed]

173. Tison, J.-M.; de Foucault, B. Flora Gallica. Flore de France; Biotope Éditions: Mèze, France, 2014.

174. Vangjeli, J. Excursion Flora of Albania; Koeltz Scientific Books: Königstein, Germany, 2015.

175. Dimopoulos, P.; Raus, T.; Bergmeier, E.; Constantinidis, T.; Iatrou, G.; Kokkini, S.; Strid, A.; Tzanoudakis, D. Vascular plants of Greece: An annotated checklist. Supplement. Willdenowia 2016, 46, 301-347. [CrossRef]

176. Aedo, C.; Buira, A.; Medina, L.; Fernández-Albert, M. The Iberian Vascular Flora: Richness, Endemicity and Distribution Patterns. In The Vegetation of the Iberian Peninsula; Loidi, J., Ed.; Springer: Cham, Switzerland, 2017; Volume 1, pp. 101-130.

177. Danihelka, J.; Chrtek, J., Jr.; Kaplan, Z. Checklist of vascular plants of the Czech Republic. Preslia 2012, 84, 647-811.

178. Lambdon, P.W.; Pyšek, P.; Basnou, C.; Arianoutsou, M.; Essl, F.; Hejda, M.; Jarošík, V.; Pergl, J.; Winter, M.; Anastasiu, P.; et al. Alien flora of Europe: Species diversity, temporal trends, geographical patterns and research needs. Preslia 2008, 80, 101-149.

179. Arianoutsou, M.; Bazos, I.; Delipetrou, P.; Kokkoris, Y. The alien flora of Greece: Taxonomy, life traits and habitat preferences. Biol. Invasions 2010, 12, 3525-3549. [CrossRef]

180. Domingues de Almeida, J.; Freitas, H. Exotic flora of continental Portugal—A new assessment. Bocconea 2012, 24, $231-237$.

181. Barina, Z.; Rakaj, M.; Somogyi, G.; Erős-Honti, Z.; Pifkó, D. The alien flora of Albania: History, current status and future trends. Weed Res. 2014, 54, 196-215. [CrossRef]

182. Uludă̆, A.; Aksoy, N.; Yazlık, A.; Arslan, Z.F.; Yazmıs, E.; Üremiş, I.; Cossu, T.A.; Groom, Q.; Pergl, J.; Pyšek, P.; et al. Alien flora of Turkey: Checklist, taxonomic composition and ecological attributes. NeoBiota 2017, 35, 61-85. [CrossRef]

183. Blasi, C.; Filibek, G.; Burrascano, S.; Copiz, R.; Di Pietro, R.; Ercole, S.; Lattanzi, E.; Rosati, L.; Tilia, A. Primi risultati per una nuova regionalizzazione fitogeografica del territorio italiano. Biogeographia 2007, 28, 9-23. [CrossRef]

184. Pignatti, S. Ecologia del paesaggio; UTET: Torino, Italy, 1997.

185. Peruzzi, L.; Conti, F.; Bartolucci, F. An inventory of vascular plants endemic to Italy. Phytotaxa 2014, 168, 1-75. [CrossRef]

186. Abbate, G.; Scassellati, E.; Bonacquisti, S.; Iberite, M.; Latini, M.; Giuliani, A. Using woody genera for phytogeographic regionalization at a medium scale: A case study of Italy. Botany 2016, 94, 533-542. [CrossRef]

187. Hawkins, B.A.; Diniz-Filho, J.A.F. 'Latitude' and geographic patterns in species richness. Ecography 2004, 27, 268-272. [CrossRef]

188. Kessler, M.; Grytnes, J.A.; Halloy, S.R.P.; Kluge, J.; Krömer, T.; León, B.; Macía, M.J.; Young, K.R. Gradients of Plant Diversity: Local Patterns and Processes. In Climate Change Effects on The Biodiversity of The Tropical Andes; Herzog, S.K., Martinez, R., Jorgensen, P.M., Tiessen, H., Eds.; Inter-American-Institute of Global Change Research: São José dos Campos, Brazil, 2011; pp. $204-219$.

189. Ohdo, T.; Takahashi, K. Plant species richness and community assembly along gradients of elevation and soil nitrogen availability. AoB Plants 2020, 12, plaa014. [CrossRef]

190. Ramos, C.S.; Picca, P.; Pocco, M.E.; Filloy, J. Disentangling the role of environment in cross-taxon congruence of species richness along elevational gradients. Sci. Rep. 2021, 11, 4711. [CrossRef]

191. Lazarina, M.; Charalampopoulos, A.; Psaralexi, M.; Krigas, N.; Michailidou, D.E.; Kallimanis, A.S.; Sgardelis, S.P. Diversity patterns of different life forms of plants along an elevational gradient in Crete, Greece. Diversity 2019, 11, 200. [CrossRef]

192. Subedi, C.K.; Rokaya, M.B.; Münzbergová, Z.; Timsina, B.; Gurung, J.; Chettri, N.; Baniya, C.B.; Ghimire, S.K.; Chaudhary, R.P. Vascular plant diversity along an elevational gradient in the Central Himalayas, western Nepal. Folia Geobot. 2020, 55, 127-140. [CrossRef] 
193. Di Biase, L.; Pace, L.; Mantoni, C.; Fattorini, S. Variations in Plant Richness, Biogeographical Composition, and Life Forms along an Elevational Gradient in a Mediterranean Mountain. Plants 2021, 10, 2090. [CrossRef]

194. Conti, F.; Uzunov, D. Crepis magellensis F. Conti \& Uzunov (Asteraceae), a new species from Central Apennine (Abruzzo, Italy). Candollea 2011, 66, 81-86. [CrossRef]

195. Brullo, S.; Pavone, P.; Salmeri, C. Allium aetnense (Amaryllidaceae), a new species from Sicily. Plant. Biosyst. 2013, 147, 835-843. [CrossRef]

196. Španiel, S.; Kaplan, K.; Bovio, M.; Mártonfiová, L.; Cetlová, V. Alyssum rossetii (Brassicaceae), a new species from the Aosta Valley in Italy based on morphological and genome size data. Phytotaxa 2018, 360, 269-281. [CrossRef]

197. Olden, J.D. Biotic homogenization: A new research agenda for conservation biogeography. J. Biogeogr. 2006, 33, 2027-2039. [CrossRef]

198. Seebens, H.; Bacher, S.; Blackburn, T.M.; Capinha, C.; Dawson, W.; Dullinger, S.; Genovesi, P.; Hulme, P.E.; van Kleunen, M.; Kühn, I.; et al. Projecting the continental accumulation of alien species through to 2050. Glob. Change Biol. 2021, 27, 970-982. [CrossRef] 